\title{
Cultural heritage of Poland in the urban space of Vienna
}

\author{
Karol Witkowski - Szymon Kowalik - Barbara Czerwińska - Aleksandra Kędzior - \\ Agnieszka Obermajer - Jakub Pałucki - Weronika Sikorska
}

Karol Witkowski, PhD

Pedagogical University of Krakow

Institute of Geography

Department of Geoinformation

and Environmental Research

Podchorążych St. $2 / 427$

30-084 Krakow

Poland

e-mail: karol.witkowski@up.krakow.pl

ORCID: 0000-0002-0910-9374

Szymon Kowalik, MSc

Pedagogical University of Krakow

Institute of Geography

Department of Geology

Podchorażych St. 2/535

30-084 Krakow

Poland

e-mail: szymon.kowalik@up.krakow.pl

ORCID: 0000-0002-3941-6818

Barbara Czerwińska

Pedagogical University of Krakow

Institute of Geography

Podchorążych St. 2/520

30-084 Krakow

Poland

e-mail: barbara.czerwinska@student.up.krakow.pl

ORCID: 0000-0002-5144-4168
Aleksandra Kędzior

Institute of Geography

Podchorażzych St. 2/520

30-084 Krakow

Poland

e-mail: aleksandra.kedzior@student.up.krakow.pl

ORCID: 0000-0002-6192-8238

Agnieszka Obermajer

Institute of Geography

Podchorażych St. 2/520

30-084 Krakow

Poland

e-mail: agnieszka.obermajer@student.up.krakow.pl ORCID: 0000-0002-1137-998X

Jakub Pałucki, Bsc

Institute of Geography

Podchorażych St. 2/520

30-084 Krakow

Poland

e-mail: jakub.palucki@student.up.krakow.pl

ORCID: 0000-0003-1105-0292

Weronika Sikorska

Institute of Geography

Podchorażych St. 2/520

30-084 Krakow

Poland

e-mail: weronika.sikorska@student.up.krakow.pl

ORCID: 0000-0002-6045-8107

Muzeológia a kulturne dedičstvo, 2021, 9:3:17-41

DOI: $10.46284 / \mathrm{mkd} .2021 .9 .3 .2$

Cultural heritage of Poland in the urban space of Vienna

The aim of the research was to define the cultural heritage of Poland as represented in the urban space of Vienna by Polonica. Structures commemorating Poles or events they took part in, as well as places related to Poland and Polish people such as Nazi death camps, or geographical objects, were included. Polonica were grouped and analysed in terms of the time of creation, location in the city space, founders, inscriptions and building materials (if they came from Poland). On the basis of the results and discussion, it was found that, as a group of objects, Polonica represent the cultural heritage of Poland from various periods. These objects show both the history of the people and events commemorated, as well as events in the history of Poland over the last 400 years. Moreover, it was argued that some Polonica constitute the cultural heritage of both Poland and Austria. Some objects may be perceived and interpreted differently, which may be related to international political disputes.

Keywords: Polonica, cultural heritage, history of Poland, Vienna 


\section{Cultural heritage outside the country}

The first definition of cultural heritage was proposed in the International Venice Charter in 1964. For a long time, the only determinants for classifying an object as a cultural heritage site were its historical and artistic values. Over time, however, other parameters were also added, such as cultural value, identity and the object's ability to interact with memory. ${ }^{1}$ Thanks to these changes, what can be considered cultural heritage is what those living today want to pass on from the past to future generations. ${ }^{2}$ Such a broad definition of heritage also includes objects commemorating events or people from the past, such as monuments and plaques. These objects, in their form, do not have to be considered heritage, because this is determined by the content for which they are the carrier. ${ }^{3}$ According to Dabezies, heritage is the result of a greater interest in one object than in others. ${ }^{4}$ Inheritance is a metacultural process dependent on external events that turn an object into heritage. ${ }^{5}$ Heritage objects always have strong cultural references. Therefore, cultural heritage can include both a cathedral and a traditional dance. ${ }^{6}$ The inheritance perspective is a growing field of research on the processes of creating cultural and natural heritage. ${ }^{7}$ By contrast, according to Authorised Heritage Discourse (AHD), heritage sites must have a rich history, be of great significance to the nation and be valued by experts. ${ }^{8}$ Smith criticises this approach by arguing that heritage is not an object, place or event, but is a cultural process involving remembering and understanding. ${ }^{9}$ Researchers are increasingly treating heritage not in AHD terms but as a discourse,${ }^{10}$ debate $^{11}$ or process. ${ }^{12}$

Objects located outside the borders of a given country are an important type of its cultural heritage. In this case, for the observer, their origin is more important than the artistic value of these objects. ${ }^{13}$ Poland has, among other assets, rich cultural heritage resources, also known

${ }^{1}$ VECCO, Marilena. A definition of cultural heritage: From the tangible to the intangible. In: Journal of Cultural Heritage, 11(3), 2010, pp. 321-324.

${ }^{2}$ GRAHAM, Brian, ASHWORTH, Gregory, TUNBRIDGE, John. A Geography of Heritage: Power, Culture, and Economy. London: Arnold, 2000.

${ }^{3}$ FAIRCLOUGH, Graham. New heritage frontiers. In: PALMER, Robert (ed.). Heritage and Beyond. Strasbourg: Council of Europe Publishing, 2009, pp. 29-41.

${ }^{4}$ DABEZIES, Juan Martin. Heritagization of nature and its influence on local ecological knowledge in Uruguay. In: International Journal of Heritage Studies, 24(8), 2018, pp. 828-842.

${ }^{5}$ KIRSHENBLATT-GIMBLETT, Bárbara. El patrimonio inmaterial como producción metacultural. In: Museum International, 221(222), 2004, pp. 52-65.

${ }^{6}$ DABEZIES, Heritagization of nature...

7 BENDIX, Regina. Heritage between Economy and Politics. An Assessment from the Perspective of Cultural Anthropology. In: SMITH, Laurajane, AKAWA, Natsuko (eds.). Intangible Heritage. London: Routledge, 2009, pp. 253-269; SMITH, Laurajane. Uses of Heritage. London: Routledge, 2006.

${ }^{8}$ SMITH, Uses of Heritage...

${ }^{9}$ SMITH, Laurajane. El „espejo patrimonial“: illusion narcisista o reflexiones multiples? In: Antipoda: Revista de Antropología y Arqueología, 2011, pp. 39-63.

${ }^{10}$ BYRNE, Denis. Deep Nation: Australia's Acquisition of an Indigenous past. In: Aboriginal History, 20, 1996, pp. 82-107; HALL, Stuart. Whose Heritage? Un-settling “The Heritage”, Re-imaging the Post-Nation. In: Third Text, 13(49), 1999, pp. 3-13; WATERTON, Emma. Towards a Critical Heritage: Discourse, Policy and Power. Basingstoke: Palgrave Macmillan, 2010.

${ }_{11}$ TUNBRIDGE, John, ASHWORTH, Gregory. Dissonant Heritage. Chichester: Wiley, 1996; GRAHAM, ASHWORTH, TUNBRIDGE, A Geography of Heritage...

${ }^{12}$ HARVEY, David C. Heritage Pasts and Heritage Presents: Temporality, Meaning and the Scope of Heritage Studies. In: International Journal of Heritage Studies, 7(4), 2001, pp. 319-338; GRANT, Hilary. Heritage down the chute: the demolition of Saskatchewan's grain elevators. In: International Journal of Heritage Studies, 24(6), 2018, pp. 573-584. ${ }^{13}$ PIASTA, Marek. Polskie dziedzictwo kulturowe na Lotwie - niewykorzystany potencjał turystyczny. In: Turystyka Kulturowa, 8, 2011, pp. 30-49. 
as Polonica, outside its borders. Polonica are written documents, works of art, national or historical memorials, as well as places of Polish origin or thematically related to Poland, which are located abroad. The Polish word "polonik" comes from the Latin polonicum or polonica. ${ }^{14}$ The Polish language uses analogous terms for the cultural heritage of other countries: JudaicaJewish, Bohemica - Czech, Hispanica - Spanish, Rossica - Russian etc.

Polonica, in the sense of works of art of Polish origin, are widely presented in academic literature. Among other things, the paintings of Polish artists in Ukrainian museums have been discussed. Goch describes the history of the inventory of museums in Kharkiv, Kiev, Uman and Chernivtsi, where paintings of, among others, Aleksander Kokular, Henryk Siemiradzki, Jan Ścieliński, Augusta Kochanowska and Artur Kolnik have been found. ${ }^{15}$ The works of Siemiradzki or Ciagliński are also on view in St Petersburg in Russia. ${ }^{16}$ Books, ephemera and archives from foreign collections and libraries are an important group of Polonica. One representative example of these resources is the Stanford University Library in California. In her article, Krupa discusses not only the collections, but also the process of searching and developing Polish materials, and the profiles of Polish academics associated with the university. ${ }^{17}$ A large collection of Polonica is also located in the Bavarian State Library in Munich. ${ }^{18}$ The collections of the Slavic Institute in Bratislava and the history of its establishment are presented by Skovierova. ${ }^{19}$ As part of joint Polish-Swedish research, a number of hitherto unknown Polonica have been inventoried at the Swedish National Archives. The main subject of research at that time was the "Skoklostersamlingen. Polska brev och handlingar" collection. ${ }^{20}$

Understood as objects commemorating Poles abroad, Polonica have been discussed, inter alia, by Piasta on the basis of the example of palaces, churches and monuments in Latvia. ${ }^{21}$ In his text, the author shows the great potential of the Polish cultural heritage in this region. Piasta proposes the creation of a cultural route promoting the Polish heritage. Piasta and Kamel (2013) presented Polonica also in Estonia. The authors emphasised, inter alia, the activities of the Estonian Polish community, actively caring for the commemoration of places and events related to Poles. ${ }^{22}$ Skrodzka, on the other hand, focused on presenting the Polonica found in

\footnotetext{
${ }^{14}$ Wielke Encykelopedia Powszechna PWN, vol. 8, Warszawa, 1966, p. 837.

${ }^{15}$ GOCH, Marcin. Zapomniane malarskie polonika w zbiorach muzeów Ukrainy. In: WALCZAK, Wojciech, ŁOPATECKI, Karol, eds. Stan badań nad wielokulturowym dziedzictwem dawnej Rzecsypospolitej, t. IX. Białystok: Instytut Badań nad Dziedzictwem Kulturowym Europy, 2017, pp. 383-394.

${ }^{16}$ KONSTANTYNÓW, Dariusz, ed. Petersburg i Polska: z̧biór esejów. Kraków: Międzynarodowe Centrum Kultury, 2016; GÓRENOWICZ, Maria. Akademickie prace Jana Ciaglińskiego (1858-1913). In: Art of Eastern Europe, 4, 2016, pp. 401-409.

${ }^{17}$ KRUPA, Barbara, NAFPAKTITIS, Margarita. Polonika w Bibliotece Uniwersytetu Stanforda w Kalifornii: unikalne kolekcje, trudności w gromadzeniu i udostępnianiu. In: Z Badań nad Ksiażka i Ksiegozbiorami Historycznymi, Polonika w zbiorach obcych, spec. vol., 2017, pp. 557-566.

${ }^{18}$ KUNZ, Norbert. Polonica der Bayerischen Staatsbibliothek - Bestände und digitale Dienstleistungen. In: $Z$ Badań nad Ksiażkeq i Ksiegozbiorami Historycznymi, Polonika w zbiorach obcych, spec. vol., 2017, pp. 345-356.

${ }^{19}$ ŠKOVIEROVA, Angela. Polonica in the library of the Slavic Institute in Bratislava. In: Z Badan nad Ksiażka $i$ Ksiegozbiorami Historycznymi, Polonika w zbiorach obcych, spec. vol., 2017, pp. 381-386.

${ }^{20}$ NOWICKA-JEZOWA, Alina, TEODOROWICZ-HELLMAN, Ewa, eds. Polonica in the Swedish National Archives: The Skokloster Collection and Other Materials. Stockholm: Stockholms Universitet Slaviska Institutionen, 2007.

${ }^{21}$ PIASTA, Polskie dziedzictwo kulturowe na Lotwie...

${ }^{22}$ PIASTA, Marek, KAMEL, Marta. Polskie dziedzictwo kulturowe w Estonii - potencjał turystyczny. In: Turystyka Kulturowa, 6, 2013, pp. 46-64.
} 
one building, i.e. in the Notre-Dame de Bonsecours church in Nancy. ${ }^{23}$

Numerous cases of the cultural heritage of other nations on the territory of Poland have also been documented - among others, Judaica, ${ }^{24}$ American monuments, ${ }^{25}$ works of Italian artists, including in Krakow, Zamość and Warsaw ${ }^{26}$ and in the Świętokrzyska Land, ${ }^{27}$ memorabilia of the Napoleonic era, ${ }^{28}$ the heritage of Dutch settlers, ${ }^{29}$ and German cemeteries in western Poland. ${ }^{30}$ A large book on Hungarian mementoes ${ }^{31}$ and Ukrainian memorial sites located in Poland has been published. ${ }^{32}$ The heritage of Polish border areas has been discussed in an international context. Among others, the cultural heritage of the Nysa-Jesenice borderland in terms of historical cemeteries and remembrance sites on the Polish and Czech side, ${ }^{33}$ Polish, Czech and German mementoes of the Silesian Wars ${ }^{34}$ and the Polish-German heritage of Pomerania $^{35}$ have been presented.

The National Institute of Polish Cultural Heritage Abroad, POLONIKA, is responsible for the dissemination of knowledge about Polonica among people interested in the cultural heritage of Poland. Using the Arts\&Culture.google.com tool, this institution presents virtual exhibitions of Polonica. The first of them is "Polish Cathedrals" showing Polish churches in America, including the oldest, St Stanisław Kostka's church in Chicago, dating back to 1877. Another exhibition is entitled "Poles in Liepaja: A Polish chapter in the history of the Latvian city". ${ }^{36}$ The Polish Ministry of Foreign Affairs has made the "Atlas of Polish Presence Abroad" available on the Internet. The publication contains maps, descriptions and collected information presenting traces of the presence of Polish emigration in the world. The project is the result of the work of the Ministry of Foreign Affairs, which has gathered knowledge and information

\footnotetext{
${ }^{23}$ SKRODZKA, Agnieszka. Polonika w kościele Notre-Dame de Bonsecours w Nancy. In: ROLSKA, Irena (ed.). Studia nad sztuka renesansu i baroku. T. 14, Twórca i dzieło, Lublin: Towarzystwo Naukowe Katolickiego Uniwersytetu Lubelskiego Jana Pawła II, 2019, pp. 149-174.

${ }^{24}$ MAŁKOWSKA-BIENIEK, Ewa. Polskie judaika jako magnes turystyczny. In: Turystyka Kulturowa, 4, 2009, pp. 29-62.

${ }^{25}$ PARAFIANOWICZ, Halina. Woodrow Wilson and Poland: Between Myth and Reality. Some Reflections. In: Białostockie Teki Historyczne, 16, 2018, pp. 129-145.

${ }^{26}$ TYGIELSKI, Wojciech. Włosi. In: KOPCZYŃSKI, Michał, TYGIELSKI, Wojciech (eds.). Pod wspólnym niebem. Narody dawnej Rzecsypospolitej. Warszawa: Muzeum Historii Polski, 2010, pp. 183-200.

${ }^{27}$ DLUGOSZ, Dominika. Śladami Włochów w Polsce od XVI do XVIII wieku. Region świętokrzyski. In: Rocznik Muгeum Narodowego w Kielcach, 23, 2007, pp. 167-192.

${ }^{28}$ ROJEK, Katarzyna. Znaczenie pamiątek i rekonstrukcji historycznych epoki napoleońskiej w Polsce dla rozwoju turystyki kulturowej (historyczno-biograficznej). In: Turystyka Kulturowa, 5, 2009, pp. 4-27.

${ }^{29}$ WENDERSKI, Michał. "Dutch" settlements in Poland. How different were they actually? In: Werkwinkel, 10(1), 2015, pp. 51-64.

${ }^{30}$ STACHOWIAK, Andrzej. Niemieckie cmentarze na Ziemiach Zachodnich jako miejsca niepamięci. In: Prace Etnograficzne, 43(2), 2015, pp. 123-140.

${ }^{31}$ KOVACS, István, MITROVITS, Miklós. Wegierskie pamiatki w Polsce. Budapest: Antall József Tudásközpont, 2019.

${ }^{32}$ KRAJEWSKI, Kazimierz. Ukraińskie miejsca pamięci narodowej na terenie Polski. In: Biuletyn Instytutu Pamięci Narodowej, 7-8, 2010, pp. 118-137.

${ }^{33}$ KOLODZIEJCZYK, Krzysztof Piotr. Historyczne cmentarze i miejsca pamięci pogranicza nysko-jesenickiego jako walor krajoznawczy. In: Turystyka Kulturowa, 4, 2015, pp. 41-73.

${ }^{34}$ CHYLIŃSKA, Dagmara, KOSMALA, Gerard. Krajobraz po bitwie. Niewykorzystany potencjał turystyczny pól bitew na przykładzie wojen śląskich. In: WIDAWSKI, Krzysztof (ed.). Turystyka kulturowa na Dolnym Ślasku - wybrane aspekty, Tom 2. Wrocław: Uniwersytet Wrocławski, 2011, pp. 33-70.

${ }^{35}$ KUS, Eugeniusz, MAKOWSKA, Beata. Wspólne dziedzictwo na Pomorzu. In: Ochrona Zabytków, 2, 2007, pp. 17-19.

${ }^{36}$ KUC, Monika. Polonika w świecie na Google Arts \& Culture. In: Rzeczpospolita, 24.06.2020, accessed October 13, 2020, https://www.rp.pl/Spoleczenstwo/200629692-Polonika-w-swiecie-na-Google-Arts--Culture.html.
} 
about the Polish community and its activities outside Poland. Thirty-three countries were discussed in the study, including Austria. ${ }^{37}$ The Ministry of Culture and National Heritage of the Republic of Poland has created an internet portal which collects information about objects of Polish cultural heritage abroad. In the case of the Viennese Polonica, the pictures of Jan Henryk de Rosen in the church on the Kahlenberg, the non-existent Lanckoroniski Palace, the destroyed sculpture by Szańkowski and the monuments in the Arsenal made by Godebski have been discussed..$^{38}$

The issue of Polish mementoes in Vienna has already been discussed in the literature, but the question of objects located in the city space has never been discussed. Kluczycki was the first to deal with this subject, in $1835 .{ }^{39}$ He raised the issue of the legendary cathedral builders who had come from Polish lands, discussed the figures related to the Battle of Vienna, and the collections of Polish documents, books and weapons gathered in the imperial capital. Contemporary studies devoted to the Polonica in Vienna deal with the issue of book collections, ${ }^{40}$ war archives,${ }^{41}$ building plans, ${ }^{42}$ paleontological collections ${ }^{43}$ and the historical activity of Poles. ${ }^{44}$

\section{Purpose and methods}

The main aim of the research was to define the cultural heritage of Poland in the urban space of Vienna. The goal was achieved through the inventory of the Polonica located in the Austrian capital. The article also considers whether the objects representing a given country in another country are the cultural heritage of both countries.

The inventory of Polonica was narrowed down to the objects located in the space of Vienna commemorating Poles or events in which they participated. Commemorations of places, i.e. Polish geographical objects (rivers, cities, Nazi death camps) were also included. It was assumed that the inventoried objects are available to visitors outside museums and galleries, and therefore the rich set of Polish works of art was omitted. The inventory of street names commemorating Poles was also abandoned, since it had already been covered in the extensive article by CwanekFlorek, to which reference was made in this text. ${ }^{45}$

\footnotetext{
37 Atlas polskiej obecności za granica. Warszawa: Ministerstwo Spraw Zagranicznych, 2014, accessed October 11, 2020, https://issuu.com/msz.gov.pl/docs/atlas_polskiej_obecnosci_za_granica.

${ }^{38}$ Portal Polonika. Warszawa: Ministerstwo Kultury i Dziedzictwa Narodowego, accessed October 11, 2020, http:// www.polonika.gov.pl/pages/pl/idea-projektu.php

${ }^{39}$ KLUCZYCKI, Jakub F. Pamiatki polskie w Wiednin i jego okolicach. Jako też inne wiadomości tyczqce się Polaków, szcrzególniej mieszkańcón Galicji, Kraków: by the author, 1835.

${ }^{40}$ WARCHOL-SCHLOTTMANN, Małgorzata. Biblioteki polskie w Wiedniu. Od Ossolińskiego po dzień obecny. In: Prace Naukowe Uniwersytetu Ślaskiego w Katowicach, 2527, 2007, pp. 103-114.

${ }^{41}$ ROMAN, Wanda Krystyna. Aby pamięć nie zginęła? Polskie Archiwum Wojenne (1915-1921) i jego zbiory. In: Archeion, 120, 2019, pp. 185-202.

${ }^{42}$ OPYRCHAŁ, Leszek. Rękopiśmienne plany Kamieńca Podolskiego w zbiorach Austriackiej Biblioteki Narodowej w Wiedniu. In: Przeglad Historyczno-Wojskowy, 16(67)/4(254), 2015, pp. 131-140.

${ }^{43}$ PAWŁAK, Wojciech, CZEPIŃSKI, Łukasz, MAJCHRZYK, Aleksander, DUK, Katarzyna. Przegląd skamieniałości kręgowców i flory z terenów dzisiejszej Polski zgromadzonych w Muzeum Historii Naturalnej w Wiedniu. In: Przeglad Geologiczny, 67(1), 2019, pp. 48-55.

44 TABORSKI, Roman. W'sód wiedenskich poloników. Kraków: Wydawnictwo Literackie, 1974.

${ }^{45}$ CWANEK-FLOREK, Ewa. Wiedeńczyka o wiele więcej łączy z mieszkańcem Krakowa czy Budapesztu, aniżeli z mieszkańcem Berlina. Recepcja relacji polsko-austriackich z perspektywy „polskich” ulic w Wiedniu. In: KISZTELIŃSKA-WĘGRZYŃSKA, Agnieszka, KUCZYŃSKI, Krzysztof (eds.). Austria i relacje polsko-austriackie w XX $i$ XXI wieku. Polityka - kultura - gospodarka. Lódź: Wydawnictwo Uniwersytetu Lódzkiego, 2014, pp. 261-279.
} 
K. Witkowski et al.: Cultural heritage of Poland in the urban space of Vienna
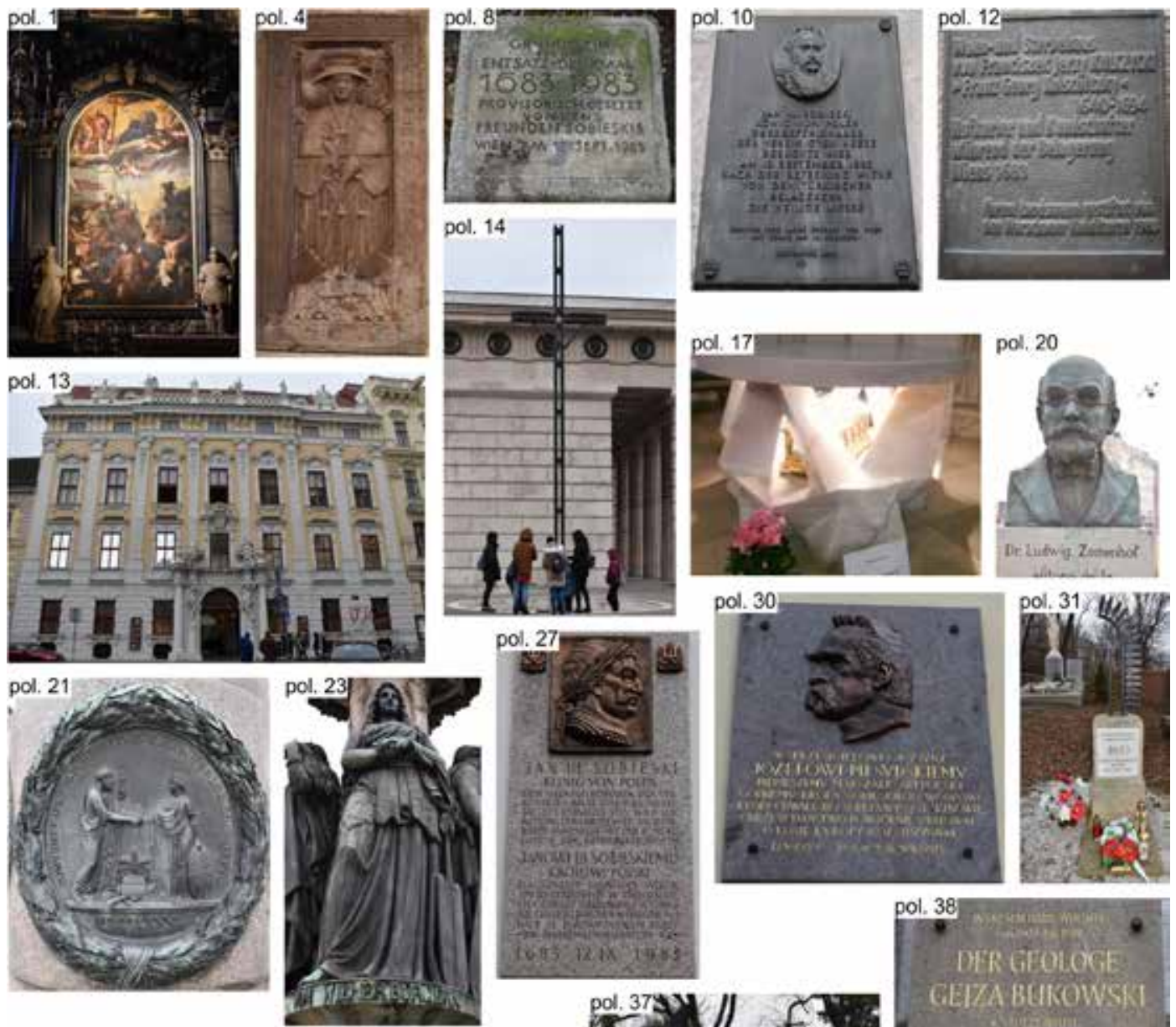

pol. 38
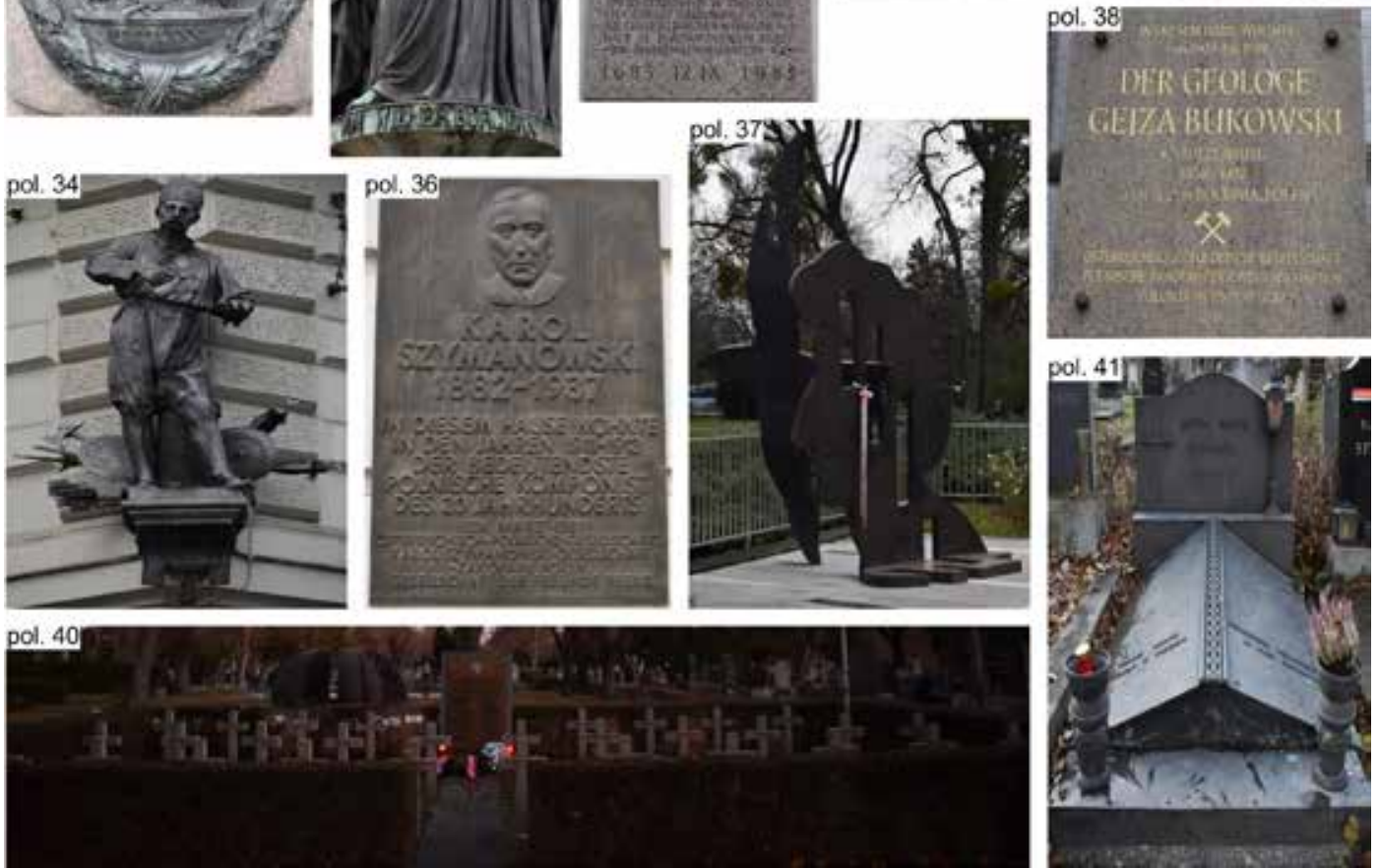

Fig. 1. Selected photos of Polonica. Object numbering is in line with table 1. 
Tab. 1. Brief characteristics of inventoried objects

\begin{tabular}{|c|c|c|c|c|c|c|}
\hline no. & object name & $\begin{array}{l}\text { location in the } \\
\text { district }\end{array}$ & $\begin{array}{l}\text { profession of } \\
\text { commemorated } \\
\text { or role/reason } \\
\text { for which com- } \\
\text { memorated }\end{array}$ & $\begin{array}{l}\text { time of object } \\
\text { construction }\end{array}$ & $\begin{array}{l}\text { object descrip- } \\
\text { tion }\end{array}$ & $\begin{array}{l}\text { type of comme- } \\
\text { moration }\end{array}$ \\
\hline 1 & $\begin{array}{l}\text { Dębnik marble } \\
\text { in the main altar } \\
\text { of St Stephen's } \\
\text { cathedral }\end{array}$ & 1. Innere Stadt & $\begin{array}{l}\text { geographical } \\
\text { object }\end{array}$ & before 1795 & none & object element \\
\hline 2 & $\begin{array}{l}\text { the urn with the } \\
\text { soil and ashes of } \\
\text { prisoners from } \\
\text { Auschwitz and } \\
\text { Mauthausen }\end{array}$ & 1. Innere Stadt & the Holocaust & after 1918 & Latin inscriptions & grave \\
\hline 3 & $\begin{array}{l}\text { the painting and } \\
\text { relics of John } \\
\text { Paul II }\end{array}$ & 1. Innere Stadt & clergyman & after 1918 & none & object \\
\hline 4 & $\begin{array}{l}\text { the tombstone of } \\
\text { Bishop Aleksan- } \\
\text { der Mazowiecki }\end{array}$ & 1. Innere Stadt & clergyman & before 1795 & Latin inscriptions & grave \\
\hline 5 & $\begin{array}{l}\text { the statue of } \\
\text { John III Sobieski } \\
\text { in the miniature } \\
\text { of the destroyed } \\
\text { altara }\end{array}$ & 1. Innere Stadt & battle & after 1918 & $\begin{array}{l}\text { German inscrip- } \\
\text { tions }\end{array}$ & altar element \\
\hline 6 & $\begin{array}{l}\text { Tomasz Soltyk's } \\
\text { tomb in the } \\
\text { cathedral cata- } \\
\text { combs }\end{array}$ & 1. Innere Stadt & politician & before 1795 & Latin inscriptions & grave \\
\hline 7 & $\begin{array}{l}\text { Andrzej } \\
\text { Poniatowski's } \\
\text { tomb in the } \\
\text { cathedral cata- } \\
\text { combs }\end{array}$ & 1. Innere Stadt & soldier & before 1795 & Latin inscriptions & grave \\
\hline 8 & $\begin{array}{l}\text { the cornerstone } \\
\text { for the con- } \\
\text { struction of the } \\
\text { John III Sobieski } \\
\text { monument }\end{array}$ & 1. Innere Stadt & battle & after 1918 & $\begin{array}{l}\text { German inscrip- } \\
\text { tions }\end{array}$ & $\begin{array}{l}\text { commemorative } \\
\text { plaque }\end{array}$ \\
\hline 9 & $\begin{array}{l}\text { the bust of Fran- } \\
\text { ciszek Jan Smolka } \\
\text { in the parliament } \\
\text { building }\end{array}$ & 1. Innere Stadt & politician & 1795-1918 & $\begin{array}{l}\text { German inscrip- } \\
\text { tions }\end{array}$ & monument \\
\hline 10 & $\begin{array}{l}\text { the plaque com- } \\
\text { memorating John } \\
\text { III Sobieski in } \\
\text { the Augustinian } \\
\text { church }\end{array}$ & 1. Innere Stadt & battle & after 1918 & $\begin{array}{l}\text { German inscrip- } \\
\text { tions }\end{array}$ & $\begin{array}{l}\text { commemorative } \\
\text { plaque }\end{array}$ \\
\hline 11 & $\begin{array}{l}\text { Stanisław } \\
\text { Potocki's epitaph } \\
\text { in Franziskaner- } \\
\text { kirche }\end{array}$ & 1. Innere Stadt & battle & before 1795 & Latin inscriptions & grave \\
\hline 12 & $\begin{array}{l}\text { the plaque } \\
\text { commemorating } \\
\text { Franciszek Jerzy } \\
\text { Kulczycki }\end{array}$ & 1. Innere Stadt & battle & after 1918 & $\begin{array}{l}\text { German inscrip- } \\
\text { tions }\end{array}$ & $\begin{array}{l}\text { commemorative } \\
\text { plaque }\end{array}$ \\
\hline 13 & Palais Kinski & 1. Innere Stadt & soldier & before 1795 & none & object \\
\hline 14 & Papal cross & 1. Innere Stadt & clergyman & after 1918 & $\begin{array}{l}\text { German inscrip- } \\
\text { tions }\end{array}$ & monument \\
\hline 15 & $\begin{array}{l}\text { Altar of St Sta- } \\
\text { nisław Kostka in } \\
\text { St Anna's church }\end{array}$ & 1. Innere Stadt & clergyman & before 1795 & none & object \\
\hline 16 & $\begin{array}{l}\text { the plaque in } \\
\text { the place of Sta- } \\
\text { nisław Kostka's } \\
\text { house }\end{array}$ & 1. Innere Stadt & clergyman & before 1795 & Latin inscriptions & object \\
\hline
\end{tabular}


K. Witkowski et al.: Cultural heritage of Poland in the urban space of Vienna

\begin{tabular}{|c|c|c|c|c|c|c|}
\hline 17 & $\begin{array}{l}\text { the tomb of } \\
\text { Clement Maria } \\
\text { Hofbauer in the } \\
\text { Maria am Gesta- } \\
\text { de church }\end{array}$ & 1. Innere Stadt & clergyman & 1795-1918 & $\begin{array}{l}\text { German inscrip- } \\
\text { tions }\end{array}$ & grave \\
\hline 18 & $\begin{array}{l}\text { the painting of } \\
\text { Maximilian Maria } \\
\text { Kolbe in Minori- } \\
\text { tenkirche }\end{array}$ & 1. Innere Stadt & clergyman & after 1918 & none & object \\
\hline 19 & $\begin{array}{l}\text { the plaque } \\
\text { commemorating } \\
\text { Frederic Chopin }\end{array}$ & 1. Innere Stadt & artist & after 1918 & $\begin{array}{l}\text { German inscrip- } \\
\text { tions }\end{array}$ & $\begin{array}{l}\text { commemorative } \\
\text { plaque }\end{array}$ \\
\hline 20 & $\begin{array}{l}\text { the bust of } \\
\text { Ludwik Zame- } \\
\text { nhof }\end{array}$ & 1. Innere Stadt & academic & after 1918 & $\begin{array}{l}\text { Esperanto } \\
\text { inscriptions }\end{array}$ & monument \\
\hline 21 & $\begin{array}{l}\text { the medallions } \\
\text { commemorating } \\
\text { the granting } \\
\text { of a charter to } \\
\text { the Kingdom } \\
\text { of Galicia and } \\
\text { Lodomeria }\end{array}$ & 1. Innere Stadt & $\begin{array}{l}\text { geographical } \\
\text { object }\end{array}$ & 1795-1918 & Latin inscriptions & $\begin{array}{l}\text { monument } \\
\text { element }\end{array}$ \\
\hline 22 & $\begin{array}{l}\text { the national em- } \\
\text { blem of Poland } \\
\text { in the finial of } \\
\text { The Albertina } \\
\text { façade }\end{array}$ & 1. Innere Stadt & $\begin{array}{l}\text { geographical } \\
\text { object }\end{array}$ & 1795-1918 & none & object element \\
\hline 23 & $\begin{array}{l}\text { the Austria } \\
\text { Fountain }\end{array}$ & 1. Innere Stadt & $\begin{array}{l}\text { geographical } \\
\text { object }\end{array}$ & 1795-1918 & none & $\begin{array}{l}\text { monument } \\
\text { element }\end{array}$ \\
\hline 24 & $\begin{array}{l}\text { the plaque com- } \\
\text { memorating Nazi } \\
\text { concentration } \\
\text { camps }\end{array}$ & 1. Innere Stadt & the Holocaust & after 1918 & $\begin{array}{l}\text { German inscrip- } \\
\text { tions }\end{array}$ & $\begin{array}{l}\text { commemorative } \\
\text { plaque element }\end{array}$ \\
\hline 25 & $\begin{array}{l}\text { the Monument } \\
\text { at Judenplatz to } \\
\text { the Victims of } \\
\text { Concentration } \\
\text { Camps }\end{array}$ & 1. Innere Stadt & the Holocaust & after 1918 & $\begin{array}{l}\text { Latin and Ger- } \\
\text { man inscriptions }\end{array}$ & $\begin{array}{l}\text { monument } \\
\text { element }\end{array}$ \\
\hline 26 & $\begin{array}{l}\text { Buffet Trześ- } \\
\text { niewski }\end{array}$ & 1. Innere Stadt & other & 1795-1918 & $\begin{array}{l}\text { German inscrip- } \\
\text { tions }\end{array}$ & object \\
\hline 27 & $\begin{array}{l}\text { St. Joseph's } \\
\text { church on the } \\
\text { Kahlenberg }\end{array}$ & 19. Döbling & battle & before 1795 & $\begin{array}{l}\text { Polish and Ger- } \\
\text { man inscriptions }\end{array}$ & $\begin{array}{l}\text { object with a } \\
\text { commemorative } \\
\text { plaque }\end{array}$ \\
\hline 28 & $\begin{array}{l}\text { the plaque } \\
\text { commemorating } \\
\text { the visit of John } \\
\text { Paul II }\end{array}$ & 19. Döbling & clergyman & after 1918 & $\begin{array}{l}\text { Polish and Ger- } \\
\text { man inscriptions }\end{array}$ & $\begin{array}{l}\text { commemorative } \\
\text { plaque }\end{array}$ \\
\hline 29 & $\begin{array}{l}\text { the plaque } \\
\text { commemorating } \\
\text { Józef Piłsudski }\end{array}$ & 19. Döbling & politician & after 1918 & $\begin{array}{l}\text { Polish inscrip- } \\
\text { tions }\end{array}$ & $\begin{array}{l}\text { commemorative } \\
\text { plaque }\end{array}$ \\
\hline 30 & $\begin{array}{l}\text { the foundation of } \\
\text { the John III So- } \\
\text { bieski monument }\end{array}$ & 19. Döbling & battle & after 1918 & $\begin{array}{l}\text { Polish, German } \\
\text { and English } \\
\text { inscriptions }\end{array}$ & $\begin{array}{l}\text { commemorative } \\
\text { plaque }\end{array}$ \\
\hline 31 & $\begin{array}{l}\text { the monument to } \\
\text { the soldiers who } \\
\text { died in the defen- } \\
\text { ce of Vienna, at } \\
\text { the place of their } \\
\text { burial }\end{array}$ & 19. Döbling & battle & before 1795 & $\begin{array}{l}\text { Polish and Ger- } \\
\text { man inscriptions }\end{array}$ & monument \\
\hline 32 & $\begin{array}{l}\text { the tomb of } \\
\text { Resurrectionist } \\
\text { priests }\end{array}$ & 19. Döbling & clergyman & 1795-1918 & Latin inscriptions & grave \\
\hline 33 & $\begin{array}{l}\text { the tomb of } \\
\text { Jarosław Maad- } \\
\text { roszkiewicz }\end{array}$ & 19. Döbling & artist & after 1918 & $\begin{array}{l}\text { Polish and Ger- } \\
\text { man inscriptions }\end{array}$ & grave \\
\hline 34 & $\begin{array}{l}\text { the monument to } \\
\text { Franciszek Jerzy } \\
\text { Kulczycki }\end{array}$ & 4. Wieden & battle & 1795-1918 & $\begin{array}{l}\text { German inscrip- } \\
\text { tions }\end{array}$ & monument \\
\hline
\end{tabular}




\begin{tabular}{|c|c|c|c|c|c|c|}
\hline 35 & $\begin{array}{l}\text { the plaque } \\
\text { commemorating } \\
\text { Stanisław Wys-- } \\
\text { piański }\end{array}$ & 2. Leopoldstadt & artist & 1795-1918 & $\begin{array}{l}\text { German inscrip- } \\
\text { tions }\end{array}$ & $\begin{array}{l}\text { commemorative } \\
\text { plaque }\end{array}$ \\
\hline 36 & $\begin{array}{l}\text { the plaque } \\
\text { commemorating } \\
\text { Karol Szyma- } \\
\text { nowski }\end{array}$ & 4. Wieden & artist & after 1918 & $\begin{array}{l}\text { German inscrip- } \\
\text { tions }\end{array}$ & $\begin{array}{l}\text { commemorative } \\
\text { plaque }\end{array}$ \\
\hline 37 & $\begin{array}{l}\text { the monument to } \\
\text { Frederic Chopin }\end{array}$ & 3. Landstraße & artist & after 1918 & $\begin{array}{l}\text { German inscrip- } \\
\text { tions }\end{array}$ & monument \\
\hline 38 & $\begin{array}{l}\text { the plaque } \\
\text { commemorating } \\
\text { Gejza Bukowski }\end{array}$ & 3. Landstraße & academic & after 1918 & $\begin{array}{l}\text { German inscrip- } \\
\text { tions }\end{array}$ & $\begin{array}{l}\text { commemorative } \\
\text { plaque }\end{array}$ \\
\hline 39 & $\begin{array}{l}\text { the sculpture of } \\
\text { the personificati- } \\
\text { on of Krakow } \\
\text { in the hall of the } \\
\text { ÖBB manage- } \\
\text { ment office }\end{array}$ & 2. Leopoldstadt & $\begin{array}{l}\text { geographical } \\
\text { object }\end{array}$ & 1795-1918 & none & monument \\
\hline 40 & $\begin{array}{l}\text { the section of } \\
\text { Polish soldiers } \\
\text { who died in the } \\
\text { years } 1939-45 \\
\text { at the Central } \\
\text { Cemetery }\end{array}$ & 11. Simmering & soldier & after 1918 & $\begin{array}{l}\text { Polish and Ger- } \\
\text { man inscriptions }\end{array}$ & grave \\
\hline 41 & $\begin{array}{l}\text { the tomb of } \\
\text { Artur Maria } \\
\text { Swinarski }\end{array}$ & 11. Simmering & artist & after 1918 & $\begin{array}{l}\text { Polish and Ger- } \\
\text { man inscriptions }\end{array}$ & grave \\
\hline 42 & $\begin{array}{l}\text { the Polish House } \\
\text { (Scientific Station } \\
\text { of the Polish } \\
\text { Academy of } \\
\text { Sciences) }\end{array}$ & 3. Landstraße & other & $1795-1918$ & $\begin{array}{l}\text { Polish and Ger- } \\
\text { man inscriptions }\end{array}$ & object \\
\hline
\end{tabular}

The research was carried out in three stages:

1. A query of journals and tourist materials was carried out in order to indicate a group of objects that constitute or may constitute Polonica. An invaluable source of information was the Viennese periodical "Polonika", edited by Mr Sławomir Iwanowski. ${ }^{46}$

2. Objects in the field were inventoried. All the objects were described using an inventory sheet prepared for this purpose. Photographic documentation (fig. 1) was also made and the exact geographic coordinates of the locations were obtained.

3. Polonica were discussed taking into account the profession of the commemorated person or the role or reason for which they are commemorated, the location of objects in the urban space of Vienna, the time of construction of the objects, the inscription and the founders. The materials from which Polonica are made was also discussed, if they came from Poland.

All of the Polonica, and their most important characteristics, are presented in table 1 . In the text, the objects in the table were referred to using their sequential number, preceded by the abbreviation "pol." (for example, "pol. 23" refers to the object "Austria Fountain").

\section{Characteristics of Polonica}

Taking into account the profession of the commemorated person, Polonica were divided into the following groups: soldiers, politicians, clergymen, artists and academics. On the other hand, objects commemorating events or places were divided into the following groups: commemoration of the Holocaust, geographical objects and others. Because of the historical importance of the Battle of Vienna, people associated with this event were included in a

\footnotetext{
${ }^{46}$ The periodical "Polonika" is published in Vienna by Österreichisch-Polnischer Verein für Kulturfreunde „Galizien". The periodical is available in the electronic version at http://polonika.at/
} 
separate group (9 objects).

The Battle of Vienna was fought on September 12, 1683 between the Polish-Imperial army commanded by the Polish King John III Sobieski and the army of the Ottoman Empire. The functioning of the Ottoman Empire in the seventeenth century was based on conquest. The Turks occupied parts of Hungary, Podolia and the Mediterranean island of Crete. The arrival of the Empire's troops at Vienna forced the Habsburgs to seek help in Poland. After losing the Battle of Vienna, the Ottoman Empire did not go on the offensive again. This battle was one of the most important European battles in determining the later fate of the continent. The key part of the battle was the charge of the hussars - cavalrymen equipped with wings made of bird feathers. This formation was made famous in Polish literature and painting - it is a model of soldierly heroism. ${ }^{47}$ In the urban space of Vienna, both the commander-in-chief John III Sobieski and soldiers of lower rank are commemorated.

The main object on the Kahlenberg commemorating the battle is the church of St Joseph (tab. 1, pol. 27) standing in the place of the former temple where a Holy Mass, which John III Sobieski attended, was celebrated before the battle. In this church there is a chamber dedicated to Sobieski, and, on the outer wall, a plaque commemorating him. In 2013, the foundation of the monument which is to present the king on horseback was erected next to the church (pol. 30). ${ }^{48}$ The third object commemorating John III Sobieski is the plaque on the eastern façade of the Augustinian church in the centre of Vienna (pol. 10). It commemorates the king's participation in the thanksgiving Mass celebrated in this church on the day after the battle. The other two commemorations of the king are not related to his direct presence in these places. The cornerstone for the construction of the Sobieski Monument (pol. 8) was laid in Shmerlingplatz, in the vicinity of the parliament, on the 300th anniversary of the battle. On the other hand, in the most important temple of Vienna, i.e. St Stephen's cathedral, there was an altar with a statue of the king, which was destroyed during World War II. Currently, there is a miniature of the altar in the cathedral (pol. 5). A monument dedicated to the Polish soldiers who died in the Battle of Vienna is located under the Kahlenberg Peak, in the place where they were buried (pol. 31). An important figure of the Battle of Vienna who has been commemorated is Franciszek Jerzy Kulczycki (Kolschitzky). He was a soldier of John III Sobieski's army who voluntarily made his way through the Ottoman camp in order to call in reinforcements for the besieged city. According to legend, as a reward for his courage Kulczycki chose sacks of coffee, which was not yet known in the west. According to the facts, after the war, he founded one of the first coffee shops in Vienna. ${ }^{49}$ On the house where he lived there is now a plaque commemorating his services (pol. 12). Another place of Kulczycki's commemoration is the tenement house in the street bearing his name, where his monument is located (pol. 34). This place is not related to his presence, and the sculpture was donated in the nineteenth century by the owner of the local café. The last Polonica related to the Battle of Vienna is the burial place of the heart of Stanisław Potocki (pol. 11), the staroste of Halych and Kolomyia, the captain and colonel of cavalry killed in the battle.

\footnotetext{
${ }^{47}$ DAVIES, Norman. God's Playground, a History of Poland: The Origins to 1795. New York: Columbia University Press, 1982, p. 487.

${ }^{48}$ ZIEMLEWSKA, Anna. Podstawa pomnika Jana III Sobieskiego na Kahlenbergu, accessed August 10, 2021, https://www.wilanow-palac.pl/sobiesciana/podstawa_pomnika_jana_iii_sobieskiego_na_kahlenbergu_sobiesciana. html.

${ }^{49}$ HOMOLA-SKĄPSKA, Irena. Krakowskie cukiernie i kawiarnie w XIX wieku. In: Annales Universitatis Mariae Curie-Sktodonska. Sectio F, Historia, 51, 1996, pp. 43-61.
} 
Three Polonica commemorating soldiers were inventoried. In the Central Cemetery, there are the quarters of Polish soldiers, prisoners of war, who died in the years 1939-45 (pol. 40). The prisoners of war were captured by Third Reich troops during the September Campaign of 1939, which started the Second World War. They were transported from Polish territory to prisoner-of-war camps in Austria and died in military hospitals. In the catacombs of St Stephen's cathedral, the Austrian army general Andrzej Poniatowski is buried (pol. 7). He was the brother of the Polish king Stanisław August Poniatowski and the father of Józef Antoni Poniatowski, who was born in Palais Kinski (pol. 13). Józef Antoni was a Polish general and commander-in-chief of the Polish Army of the Duchy of Warsaw and the Marshal of France. He was one of the leading figures in Polish history at the turn of the nineteenth century. ${ }^{50}$

Polish politicians are commemorated by three items of Polonica. In the building of the Austrian Parliament, there is a bust of Franciszek Jan Smolka (pol. 9), who was for many years a deputy of the Austrian Council of State and for many years the president of the Chamber of Deputies of the Council of State. Poles got to the Austrian parliament as deputies or officials from Galicia. This was a region in the southern part of Poland that was annexed by the Austrians during the First Partition of Poland in $1772 .{ }^{51}$ In the meeting room, there is also a plaque commemorating Polish MPs, but it is not available to tourists, and so was not included in the list. In the cathedral catacombs, there is the tomb of Tomasz Soltyk, the voivode of Łęczyca (pol. 6). This renowned politician, active in the second half of the eighteenth century, spent the last years of his life in Vienna. The last Polonicum commemorating a politician, donated by the representatives of the Viennese Polish community, is a plaque commemorating Marshal Józef Piłsudski, a leading figure in the process of the regaining of independence by Poland (pol. 29). Piłsudski was the founder of the Legions. These were Polish military units fighting under Austrian command in the First World War. In 1918, he undertook to reconstruct state structures after Poland regained its independence. ${ }^{52}$ The plaque was placed on the wall of the church on the Kahlenberg, on the anniversary of Piłsudski's death. Its location has nothing to do with the presence of the marshal in Vienna.

Among the commemorations of Polish clergymen in Vienna (9 objects), the Polonica devoted to Pope John Paul II and St Stanisław Kostka stand out. Karol Wojtyla was born in Wadowice (former Second Republic of Poland existing in the interwar period) in 1920. In 1978, he was elected Pope of the Roman Catholic Church and took the name John Paul II ${ }^{53}$ Stanislaw Kostka was the first blessed Jesuit in the history of the church. His cult began immediately after his death. ${ }^{54}$ Three Polonica commemorate John Paul II, namely the Papal Cross at Heldenplatz (pol. 14), a plaque on the church in the Kahlenberg (pol. 28) and the painting and relics of John Paul II in St Stephen's cathedral (pol. 3), made of stone from a quarry in Zakrzówek (Krakow, Poland). All of the objects refer to the presence of the Pope in these places. Another two Polonica commemorate Saint Stanisław Kostka. These are a baroque altar of the saint in St Anne's church (pol. 15), and the house of Stanisław Kostka, in which there is a chapel

\footnotetext{
${ }^{50}$ BIAŁOKUR, Marek. Defender of the Poniatowski family's honor. A story about Józef Antoni Poniatowski. In: Annales Collegii Nobilium Opolienses, 8, 2019, pp. 59-91.

${ }^{51}$ DAVIES, Norman. God's Playground, a History of Poland, Vol. 2: 1795 to the Present. New York: Columbia University Press, 2005.

${ }^{52}$ SCHWONEK, Matthew R. "Bidding up" the national cause: Józef Piłsudski and the Central Powers’ Kingdom of Poland. In: First World War Studies, 11(1), 2020, pp. 1-20.

${ }^{5}$ SZULC, Tad. Pope John Paul II: The Biography. New York: Scribner, 1995.

${ }^{54}$ COLERIDGE, Henry James. The story of St. Stanislaus Kostka of the Society of Jesus. London: Burns \& Oates, 1893.
} 
with an altar in place of the bed where Stanisław had his revelation, which is rarely made available to the faithful. On the outer wall of the building, in the window tympanum, there is a decorative inscription carrying information about the object (pol. 16). Another object is the tombstone of Bishop Aleksander Mazowiecki, the Duke of Masovia, the Tridentine bishop, and the parish priest of St Stephen in Vienna, built into the wall of the cathedral (pol. 4). In the southern nave of the Minorite church, there is a painting showing St Maximilian Maria Kolbe and concentration camp prisoners (pol. 18). St Maximilian Maria Kolbe was the founder of the Militia Immaculatae, also referred to in English as the Knights of the Immaculata, and Radio Niepokalanów, one of the first Catholic broadcasting stations in the world. He died at KL Auschwitz. ${ }^{55}$ Kolbe never visited Vienna. Another commemorated clergyman is Clement Maria Hofbauer. His tomb-reliquary is in the Maria am Gestade church (pol. 17). Hofbauer was an Austrian who worked for 21 years in Warsaw, the capital of Poland, for the poorest. ${ }^{56}$ In the cemetery near the Kahlenberg, there is a tomb of Resurrectionist priests (pol. 32) who have looked after the church in the Kahlenberg since 1906.

In the group of six Polonica commemorating artists, two are devoted to the most outstanding Polish romantic composer, Frederic Chopin. He was one of the most famous pianists of the second half of the nineteenth century. He spent the last years of his life in France. He was buried in the Père-Lachaise necropolis in Paris. ${ }^{57}$ On the wall of the tenement house in Kohlmarkt Street, which stands on the site of Chopin's house, there is a memorial plaque (pol. 19). Another object commemorating Chopin is a monument in Schweizergarten (pol. 37), the location of which has nothing to do with Chopin's activity in Vienna. Another Polonicum commemorates the stay of the playwright Stanisław Wyspiański, the author of the famous play "The Wedding", at the Hotel Nordbahn (pol. 35). Apart from literature, Wyspiański was also interested in painting, graphic art and architecture. He was one of the main artists of the Young Poland period (late nineteenth century and early twentieth century). ${ }^{58}$ The plaque on the building near St Charles Borromeo's church commemorates Karol Szymanowski, one of the greatest Polish composers, who lived there in the years 1911-1913 (pol. 36). Szymanowski became famous for skilfully weaving folk themes into his compositions. ${ }^{59}$ In the Central Cemetery, there is an open book-shaped grave in which the writer Artur Maria Swinarski is buried (pol. 41). The last Polonicum near the Kahlenberg is the grave of the composer Jarosław Mądroszkiewicz (pol. 33), who worked at the Vienna State Opera, among other places.

Among the inventoried Polonica, two are devoted to academics. The first is a bust of Ludwik Zamenhof (pol. 20), the creator of the Esperanto language, whose museum is located in Vienna. The location of the object is not directly related to Zamenhof's activity in the Austrian capital. Another Polonicum commemorates Gejza Bukowski, a geologist and palaeontologist. It is a plaque placed on the house in which he lived (pol. 38).

The three objects commemorating the Holocaust directly refer to the Polish towns and villages where Nazi concentration and extermination camps were located. The most famous of them is the Monument to the Victims of Concentration Camps at Judenplatz, where many

\footnotetext{
${ }^{55}$ STONE, Elaine Murray. Maximilian Kolbe, Saint of Auschwitr. New York: Paulist Press, 1997.

${ }^{56}$ MAGNIER, John. Blessed Clement Mary Hofbauer. In: HERBERMANN, Charles, ed. The Catholic Encyclopedia Vol. 4. New York: Robert Appleton Company, 1908, pp. 44-45.

57 ZAMOYSKI, Adam. Chopin: Prince of the Romantics. London: Harper Collins, 2010.

${ }^{58}$ KOMAROMI, Ann. Wyspianski‘s Wesele: Poised on the Border. In: Theatre Journal, 54(2), 2002, pp. $187-202$.

${ }^{59}$ SAMSON, Jim. The Music of Syymanowski, London: Kahn \& Averill, 1980. SZYMANOWSKI, Karol. Zagadnienie „ludowości” w stosunku do muzyki współczesnej. In: Musyka, 10, 1925, pp. 8-13.
} 
Polish towns and villages are mentioned (pol. 25). In the building at 15 Neutorgasse there is a plaque commemorating Jews who died at Auschwitz (pol. 24) among other places. In St Stephen's cathedral, in the Chapel of St Barbara, there is an urn with the soil and ashes of prisoners from Auschwitz (pol. 2).

There are 5 Polonica in the group of geographical objects. The Austria Fountain located near the Palais Kinski shows four figures, personifications of the major rivers that were within the boundaries of the Habsburg Monarchy, i.e. the Polish Vistula, Danube, Po and Elbe (pol. 23). In the main hall of the ÖBB management office in Nordbahnstrasse, there are four statues depicting female figures, personifications of four cities, Polish Krakow, Brno, Olomouc, and Prague, to which there used to be railway connections from this station (pol. 39). Above the front façade of the Albertina gallery, there is a richly ornamented golden cresting, with a coat of arms with the Polish Eagle and the Lithuanian Pahonia (pol. 22). The Albertina gallery itself was founded by Prince Albert Casimir of Saxony, Duke of Teschen, a son of the Polish king Augustus III of Saxony. ${ }^{60}$ On one of the four granite pedestals at Josefplatz, within the Hofburg, surrounding the statue of Joseph II, there are 2 medallions made of bronze related to Poland, commemorating the granting of a charter to the Kingdom of Galicia and Lodomeria (pol. 21). ${ }^{61}$ A very important monument of St Stephen's cathedral is the main altar, the black elements of which are made of Polish Dębnik marble (pol. 1).

Buffet Trześniewski (pol. 26) and the Polish House (pol. 42) were included in the group of other Polonica. The buffet was established by the Krakow chef Franciszek Trześniewski in 1902. It is a permanent element on the culinary map of Vienna. The Polish House was purchased by the Polish People's School Society at the beginning of the twentieth century. Later, the Polish House foundation operated there and now it is the seat of the Scientific Station of the Polish Academy of Sciences in Vienna.

\section{Location of the Polonica in the urban space}

Some of the Polonica are grouped in three locations, and the rest are scattered throughout the urban space of Vienna. There are 26 objects in the Innere Stadt district, the first district, in which the vast majority of Viennese monuments are located. As many as seven of them are in St Stephen's cathedral (pol. 1-7), e.g. the figure of John III Sobieski, the painting and relics of John Paul II, and ashes from concentration camps. Objects 8-26 are scattered within the first district mostly west of the cathedral, and only two eastwards. The second place where the Polonica are grouped (7 objects) is the Kahlenberg hill, in district 19, Döbling. On its top, there is St Joseph's church (pol. 27) and plaques commemorating John Paul II (pol. 28) and Józef Piłsudski (pol. 29), as well as the foundation of the John III Sobieski monument (pol. 30). On the southern slope of the Kahlenberg, there is a cemetery where Polish soldiers who died in the Battle of Vienna were originally buried. Among several graves from the eighteenth to twenty-first centuries, there is a monument dedicated to Polish soldiers (pol. 31) and the graves of Resurrectionist priests and of J. Mądroszkiewicz (pol. 32, 33). The third place where there is more than one Polonicum is the Central Cemetery in district 11, Simmering. There is the grave of the writer Swinarski (pol. 41) and the section of Polish soldiers who died in Vienna during World War II (pol. 40). The other seven Polonica are scattered in districts 2,

\footnotetext{
${ }^{60}$ BENEDIK, Christian, SCHRÖDER, Klaus Albrecht. Die Gründung der Albertina - Herzog Albert und seine Zeit. Ostfildern: Hatje Cantz, 2014.

${ }^{61}$ UNTERREINER, Katrin, GREDLER, Willfried. The Hofburg. Vienna: Pichler Verlag, 2009.
} 
Leopoldstadt (2 objects), 3, Landstraße (3 objects) and 4, Vienna ( 2 objects). All the Viennese Polonica are located on the right bank of the Danube. Only the objects on the Kahlenberg and in the Central Cemetery are located outside the city centre of Vienna, which is defined by the so-called Gürtel Straße.

\section{Time of creation}

Out of all 42 analysed objects, 10 were created before 1795 (before the Third Partition of Poland), 11 in the years 1795-1918 in the co-called Galician period, when the south-eastern part of Poland was under the rule of the Austrian Empire, and 21 in the period after 1918, i.e. after Poland regained its independence. In the first period, in Vienna, mainly the person of King John III Sobieski and his soldiers, as well as St Stanisław Kostka were commemorated. The burial grounds of Polish magnates, clergymen and soldiers who fought in the Battle of Vienna also date back to that time. In the Galician period, the Viennese MP Jan Smolka and the playwright Stanisław Wyspiański were commemorated. All commemorations of Polish geographical features come from that period. Their foundation emphasised that The Kingdom of Galicia and Lodomeria belonged to the Austrian empire. In the Galician period, the famous Buffet Trześniewski and the Polish House also started their activity. After the collapse of the empire in 1918, mainly Polish artists and academics were commemorated in Vienna. In the second half of the twentieth century, the victims of World War II and the person of John Paul II were commemorated. On the 300th anniversary of the Battle of Vienna, other objects commemorating King John III Sobieski were unveiled.

\section{Inscriptions and Founders}

Twenty-four Polonica have inscriptions in German or in two/three languages. The bust of Zamenhof (pol. 20), donated by the Esperanto Museum in Vienna, is described only in Esperanto. A plaque dedicated to Piłsudski (pol. 29) has the text only in Polish. It was originally installed by the efforts of the Polish community in Vienna, in the 1930s, when his person was commemorated in many places in Poland. The Polonica described in Latin, which were created in the period until 1795, are graves (pol. 4, 6, 7, 11) and the house of Stanisław Kostka (pol. 16) and dating from the period 1795-1918 are the tomb of Resurrectionist priests (pol. 32) and the medallions on the statue of Joseph II (pol. 21). The only object with a Latin inscription which was created after 1918 is an urn with ashes from Auchwitz (pol. 2). The use of Latin to describe Polonica stems from the Christian tradition of writing epitaphs. Apart from Piłsudski's plaque (pol. 29), eight more objects have descriptions in Polish. Seven of them also have a text in German (pol. 27, 28, 31, 33, 40, 41, 42), and one additionally in English (pol. 30). Objects with bilingual descriptions, even if they were created before 1918, were provided with plaques that still exist today in the second half of the twentieth century. All Polonica related to the Battle of Vienna have a description in German and possibly additionally in Polish (pol. 27, 30, 31) and English (pol. 30). Among the Polonica commemorating Polish artists, only the graves of Swinarski (pol. 41) and Mądroszkiewicz (pol. 33) have Polish and German inscriptions, and the rest only German.

Out of the eight Polonica without an in-situ description, there are four commemorations of geographical objects (pol. 1, 22, 23, 39), three commemorating clergymen located inside churches (pol. 3, 15, 18), and the palace (pol. 13), where Józef Poniatowski was born. The audioguide, which is made available to visitors, provides information about the Polish origin 
of the marble in the main altar of the cathedral (pol. 1). It is incomprehensible that there is no plaque commemorating the birthplace of Poniatowski, who is venerated in Poland as a national hero, and whose family also rendered great services to the Austrian Empire.

The plaques in Polish were placed by the Polish community or Polish organisations. Also, some plaques with descriptions only in German (pol. 8, 10, 12, 35, 36, 38, 42) were donated by institutions from Poland. Among the Polonica which are not graves, the other 18 objects are those donated by Austrian organisations.

\section{Building material and state of preservation}

Eighteen Polonica are made of stone. The most numerous group is of igneous rocks, which eight Polonica are made of (pol. 10, 14, 21, 28, 30, 32, 38, 42). Another numerous group are sedimentary rocks, which seven Polonica are made of (pol. 1, 4, 8, 20, 29, 31, 33). The fewest Polonica are made of metamorphic rocks - only three (pol. 31, 33, 42).

Three rocks from deposits located in Poland were identified. The plaque commemorating Pope John Paul II (pol. 28) on the front wall of the church on the Kahlenberg is made of Karkonosze (the Sudetes) granite, while the nearby Józef Piłsudzki plaque (pol. 29) is made of black limestone, the so-called "Dębnik marble". The foundation of the John III Sobieski monument (pol. 30) is made of Strzegom granite (the Sudetes). The main altar in the cathedral is also made of "Dębnik marble" (pol. 1). This stone was mined in Dębnik near Krakow from at least the fifteenth century as decorative stone, used mainly in sacred architecture. This stone was exported to many European countries. ${ }^{62}$

The state of preservation of all Polonica is good. The only object that is not well-kept is the cornerstone of the Sobieski monument (pol. 8). This object is in no way visible in its surroundings for it is located on a lawn. Despite the fact that the monument has not been built, the cornerstone has not been removed. However, the construction of a monument in this place should not be expected since the construction of the Sobieski monument in the Kahlenberg Hill (pol. 30) was suspended.

\section{The common message of Polonica and Polish streets}

Among the inventoried Polonica, there are nine commemorations of people related to the Battle of Vienna, nine commemorations of clergymen, six of artists, three of soldiers and politicians, and two of academics. In addition, three objects commemorate the victims of the Holocaust who were murdered in German death camps in Poland. Five Polonica commemorate Polish geographical objects. Two objects are connected with over a hundred years of activity of Poles in Vienna. In the case of commemorating Poles in the names of Viennese streets, four of them commemorate musicians and academics, three politicians, two patrons of art and writers, and one an architect and a soldier. King John III Sobieski and Prince Albert Casimir of Saxony, Duke of Teschen, were commemorated both in the name of a street and a square. ${ }^{63}$ Only King John III Sobieski and Franciszek Jerzy Kulczycki were commemorated both by Polonica and by the naming of a street. The Austrians have always been the initiators of Polish street names in Vienna. Therefore, in this way, mainly people who had rendered great services to Vienna were commemorated. On the other hand, among the Polonica there are commemorations of people (John Paul II, Frederic Chopin, Stanisław Kostka) and events (the Holocaust) known

${ }^{62}$ GRADZIŃSKI, Ryszard. Przewodnik po okolicach Krakowa. Warszawa: Wydawnictwa geologiczne, 1972, pp. 82-83.

${ }^{63}$ CWANEK-FLOREK, Wiedeńczyka o wiele więcej łączy..., p. 263. 
also outside Poland and Austria.

All the Polonica commemorating people (31 objects), except for the painting of Maximilian Maria Kolbe, are associated with their presence in Vienna. Only six of them are in places where their presence has not been confirmed. It is different in the case of the streets named after Poles. Eight out of 19 streets are related to the presence of the commemorated person in this particular place. Another eight streets are located in places not related to the activity of the commemorated people. Three people commemorated, namely the astronomer Nicolaus Copernicus, the chemist and Nobel Prize laureate Maria Skłodowska-Curie and politician Rosa Luxemburg, had never been to Vienna. ${ }^{64}$

The location of Polonica confirms the significance of the commemorated people, objects and events. As many as 26 objects are located in the first district of Vienna, of which seven are in St Stephen's cathedral. Within the immediate suburbs, districts 3-9, there are another seven Polonica. In the case of Polish-named streets, there are none in the first district, and only six in the immediate suburbs. ${ }^{65}$ The location of Polonica is another confirmation of the great role of the commemorated people in the history of Vienna and the Empire.

Half of the Polonica were established in Vienna during the Austrian Empire, 11 by 1795 and 10 during the partition of Poland until 1918. The commemoration of Poles in street names is spread over time in a very similar way. Until 1918, nine streets were named after Poles, and then $10 .{ }^{66}$ The presence of Poles in Vienna until the fall of the First Republic of Poland in 1795 resulted from the strong political ties between the Central European countries and the great importance of Vienna among European metropolises. ${ }^{67}$ The commemorating of Poles during the partitions was the result of their high political activity in the capital of the Empire. The end of the nineteenth century in Vienna was even called the "Polish rule in Austria" ${ }^{68}$ However, as Cwanek-Florek emphasises, in terms of street names, compared to the commemoration of representatives of other nations of the former Habsburg Monarchy, representatives of Bohemia and Hungary decisively outnumber Poles. ${ }^{69}$ In the context of Bohemians and Hungarians, such research has not been conducted so far.

\section{Viennese Polonica as a representation of Poland's cultural heritage - discussion of the results}

Polonica in Vienna often commemorate figures unknown to the Polish and Austrian community, and in most cases are also not historic monuments or natural attractions. Despite this, they can be recognised as cultural heritage objects outside Poland. This apparent contradiction stems from a broad definition of cultural heritage..$^{70}$ According to Fairclough,

\footnotetext{
${ }^{64}$ CWANEK-FLOREK, Wiedeńczyka o wiele więcej łączy..., p. 267.

${ }^{65}$ CWANEK-FLOREK, Wiedeńczyka o wiele więcej łączy..., pp. 266-267.

${ }^{66}$ CWANEK-FLOREK, Wiedeńczyka o wiele więcej łączy..., p. 263.

${ }^{67}$ FORST-BATTAGLIA, Jakub. Polnisches Wien. Wien-München: Herold, 1983; TABORSKI, Roman. Polacy w Wiedniu. Wrocław: Zakład Narodowy im. Ossolińskich, 1992; PESENDORFER, Franz, FISCHER, Gero. Wiener Impressionen. Auf den Spuren polnischer Geschichte in Wien. Wien: Edition Volkshochschule, 2002; CWANEK-FLOREK, Ewa. Polnische Berühmtheiten im Spiegel der öffentlichen Erinnerung in Wien. Die Rezeption polnischer Spuren in der Donaumetropole. Marburg: Tectum Wissenschaftsverlag, 2006.

${ }^{68}$ SELIGER, Maren, UCAKAR, Karl. Wien, Politische Geschichte 1740-1934. Wien-München: Jugend und Volk, 1985, p. 357.

${ }^{69}$ CWANEK-FLOREK, Wiedeńczyka o wiele więcej łączy..., p. 277.

${ }^{70}$ HEWISON, Robert. The Heritage Industry: Britain in a Climate of Decline. London: Methuen, 1987; HOWARD, Peter. Heritage. Management, Interpretation, Identity. London-New York: Continuum, 2003.
} 
ever since the importance of interpretation in understanding heritage began to be emphasised, it has become a "process". ${ }^{71}$ Showing the entire group of the Polonica in Vienna as cultural heritage gives the recipient of the message the opportunity to learn about the history of Poles in Vienna and a part of the history of Poland in general. Therefore, intangible heritage also becomes the subject of communication. ${ }^{72}$ On the other hand, in the traditional approach to heritage, most of the commemorations of Poles' activity in Vienna, which are not recognised as valuable and important historic monuments, would not deserve the name of representatives of cultural heritage. ${ }^{73}$

According to the Authorized Heritage Discourse, the Gothic tombstone of Bishop Aleksander Mazowiecki, the Baroque main altar of St Stephen's Cathedral, the Baroque Palais Kinski, the Baroque Altar of St Stanisław Kostka in St Anna's Church and the Classicist St Joseph's Church on the Kahlenberg should be regarded as examples of cultural heritage. These objects are typical examples of Gothic, Baroque and Classicist art and are part of the historical fabric of Vienna. From the point of view of art history and monument care, these objects should be protected and promoted as cultural heritage of the epochs they represent. ${ }^{74}$ However, given the narrative, tradition and history of their creation, these objects are also the cultural heritage of Poland beyond its borders.

According to Ashworth and Tunbridge, cultural heritage is what the living want to pass on from the past to future generations. ${ }^{75}$ Therefore, it cannot be unequivocally stated that the commemoration of the Battle of Vienna will constitute a value that future generations will want to care for. ${ }^{76}$ Therefore, the greatest chance for exposing the Polonica to tourists is to treat them as a group of objects that represent Poland's cultural heritage in Vienna. This approach is part of the concept of promoting the national heritage abroad. ${ }^{77}$

People who are not familiar with the history of Poland and its heritage may get to know them thanks to the commemoration of the people known outside Poland, among others Frederic Chopin or John Paul II. These figures, in connection with the Polonica that commemorate them, may even be used in activities promoting Poland in Vienna. ${ }^{78}$ The Viennese Polonica refer to the seventeenth-century history of Poland, the period of partitions, the times of World War I and II, and the history of the twentieth century. Visiting the Polonica in the urban space of Vienna, you may, therefore, learn about the most important events in the history of Poland in the last 400 years, which, apart from the message about contemporary culture and the economy, determines the image of the state. ${ }^{79}$ Thanks to the descriptions in German, this

${ }^{71}$ FAIRCLOUGH, New heritage frontiers... p. 31.

${ }^{72}$ MATIĆ, Miloš. Conceptualization of "Culture” within heritology as a paradigm. In: Anthropology, 11(1), 2011, pp. $117-142$.

${ }^{73}$ The problem of traditional and interpretative understanding of cultural heritage is widely discussed by BANASZKIEWICZ, Magdalena, OWSIANOWSKA, Sabina. Trudne dziedzictwo a turystyka. O dysonansie dziedzictwa kulturowego. In: Turystyka Kulturowa, 11, 2015, pp. 6-24.

${ }^{74}$ SMITH, Uses of Heritage...

${ }^{75}$ GRAHAM, ASHWORTH, TUNBRIDGE, A Geography of Heritage..., p. 6.

${ }^{76}$ LOWENTHAL, David. The Heritage Crusade and the Spoils of History. New York: Cambridge University Press, 1998; ASHWORTH, Gregory. Holocaust tourism: The experience of Kraków-Kazimierz. In: International Research in Geographical and Environmental Education, 11(4), 2002, pp. 363-367.

${ }^{77}$ PIASTA, Polskie dziedzictwo kulturowe na Lotwie...

${ }^{78}$ TOMCZAK, Agnieszka. Polish national branding in comparison to selected of Central and Eastern Europe. In: Journal of Modern Science, 29(2), 2016, pp. 153-174.

${ }^{79}$ LUSIŃSKA, Anna, KALINOWSKA-ŻELEŹNIK, Anna. Promocja Polski i kultury polskiej za granicą w programie Ministerstwa Kultury i Dziedzictwa Narodowego. In: Media Biznes Kultura, 1(2), 2017, pp. 77-91. 
individual guide to the history of Poland is available not only to Polish tourists and the Polish community, but also to Austrians. This is confirmed by the 18 Polonica which are not graves, which were created on the initiative of Austria, compared to 16 objects created on the initiative of Polish institutions or the Polish community in Austria. The dominance of the German language in the inscriptions on the Polonica shows that the founders of the objects, both Polish and Austrian, wanted to reach the Viennese with their message. The two most recent objects (the foundation of the Sobieski Monument on the Kahlenberg and the Holocaust Monument on Judenplatz) also have descriptions in English, which proves that they were meant to be open to foreign tourists in the twenty-first century. ${ }^{80}$

For the Viennese, apart from commemorating Slovaks, Czechs, Hungarians, Germans etc., Polonica are part of the cultural heritage of the city built by citizens of many countries. Owing to the location of many of them within district 1, visiting Polonica also makes it possible to learn about the history of Vienna. Numerous Polonica are located within the most valuable historic monuments of Vienna, such as St Stephen's cathedral, the Albertina gallery, the Minoritenkirche or the Hofburg. In this perspective, Polonica become an element of common heritage. ${ }^{81}$ However, common heritage may become the subject of a political dispute, an example of which is the construction of the John III Sobieski monument on the Kahlenberg, which has been suspended. ${ }^{82}$ This situation proves that cultural heritage may be perceived very differently by those interested in it. ${ }^{83}$ The monument itself becomes a tool for the interpretation of history. ${ }^{84}$ A common problem in Central Europe is the removal of Soviet monuments from public space, which is met with harsh reactions from representatives of the Russian Federation and Russian society. ${ }^{85}$

Polonica commemorating the Holocaust and World War II soldiers recall Poland's difficult and painful history, often referred to as martyrdom. According to Uzzell, commemorations of wars should engage with the heritage that causes pain. ${ }^{86}$ This approach challenges the idea of heritage as solace and delight. ${ }^{87}$ The polonica in Vienna are not "uncomfortable heritage" because they only commemorate a difficult history. These polonica are not in the locations

${ }^{80}$ ZAHEDPISHEH, Nahid, ABU BAKAR, Zulqarnain B., SAFFARI, Narges. English for Tourism and Hospitality Purposes (ETP). In: English Language Teaching, 10, 2017, pp. 86-94.

${ }^{81}$ ASHWORTH, Gregory, GRAHAM, Brian, TUNBRIDGE, John. Pluralising Pasts: Heritage, Identity and Place in Multicultural Societies. London-Ann Arbor: Pluto Press, 2007; TUNBRIDGE, John. Problems in selling heritage for tourism: A cautionary tale, with insight from European's (pen)insular margins. In: KAMINSKI, Jaime, BENSON, Angela, ARNOLD, David (eds.). Contemporary Issues in Cultural Heritage Tourism. London-New York: Routledge, 2013, pp. 59-70.

${ }^{82}$ DOWELL, Stuart. King Sobieski monument erected in Kraków after Vienna says it's too controversial. In: The First News, 19.11.2019. accessed December 17, 2020, https://www.thefirstnews.com/article/king-sobieski-monument-erected-in-krakow-after-vienna-says-its-too-controversial-8780

${ }^{83}$ MACDONALD, Sharon. Difficult Heritage: Negotiating the Nazi Past in Nuremberg and Beyond. London: Routledge, 2009.

${ }^{84}$ ZIĘBIŃSKA-WITEK, Anna. Musealisation of communism, or how to create national identity in historical museums. In: Mureológia a kultúrne dedicstvo, 8(4), 2020, pp. 59-72.

${ }^{85}$ SMITH, David J. "Woe from Stones" Commemoration, Identity Politics and Estonia's "War of Monuments". In: Journal of Baltic Studies, 39(4), 2008, pp. 419-430; HARRISON, Rodney. Heritage: critical approaches. New York: Routledge, 2013; CZEPCZYŃSKI, Mariusz, SOOVALI-SEPPING, Helen. From sacrum to profanum: reinterpretation of communist places of power in Baltic cities. In: Journal of Baltic Studies, 47(2), 2016, pp. 239-255.

${ }^{86}$ UZZELL, David. Heritage Interpretation - Volume 1: The Natural and Built Environment. London: Belhaven, 1989; UZZELL, David. Heritage Interpretation - Volume 2: The Visitor Experience. London: Belhaven, 1989.

${ }^{87}$ ASHWORTH, Gregory. Editorial: On Icons and ICONS. In: International Journal of Heritage Studies, 12(5), 2006, pp. 392-393. 
where the commemorated events took place. ${ }^{88}$ From the point of view of Poland's raison d'état, these polonica should be used to promote an unadulterated history that makes it clear who was the perpetrator and who was the victim.

The main recipients of the message of Polonica are tourists, who should be able to visit these objects in an organised manner. The issue of the interest of domestic tourists in Polonica has already been discussed by Piasta on the example of Latvia. ${ }^{89}$ He stated that the best way to interest Poles in visiting these objects is to create a thematic route. Also Walkowski calls for the creation of a museum route for Greek mementoes in Spain and Portugal. ${ }^{90}$ On the other hand, Czech mementoes in Polish Wrocław were presented to tourists in the form of a smartphone application, which makes it possible to get to know the history of the objects and visit them while following the proposed route. ${ }^{91}$ For representatives of the Polish community in Austria, visiting Polonica can be a way to maintain ties with their homeland, especially in the context of teaching children and young people about Poland. The role of Polonica in the life and education of the Polish community has been described, using, among other examples, those of Hungary ${ }^{92}$ and the states of the former Union of Soviet Socialist Republics. ${ }^{93} \mathrm{~A}$ good direction for the promotion of the Viennese Polonica would seem to be the creation of a virtual trail which, after being made available via an Internet application, could be used by individual tourists. From the point of view of tourists from Poland, it is necessary to enrich the content of guidebooks on Vienna, which currently indicate only objects related to the Battle of Vienna as Polish sites.

The growing popularity of geotourism in the twenty-first century also increases the possibilities of presenting cultural heritage through the prism of natural heritage. ${ }^{94}$ This possibility is also provided by presenting Polonica as objects made of rocks (18 objects). Four Polonica were made of material brought from Poland, which emphasises their natural and cultural provenance. Such presentation of Polonica results in their becoming objects of cultural tourism and geotourism. ${ }^{95}$ The cultural aspect adds value to the natural one. ${ }^{96}$

\section{Conclusions}

The cultural heritage of Poland is present in Vienna in museums and galleries and in the city space. Viennese Polonica commemorate both famous Poles who stayed only in the Austrian

\footnotetext{
${ }^{88}$ PENDLEBURY, John, WANG, Yi-Wen, LAW, Andrew. Re-using “uncomfortable heritage”: the case of the 1933 building, Shanghai. In: International Journal of Heritage Studies, 24(3), 2018, pp. 211-229.

${ }^{89}$ PIASTA, Polskie dziedzictwo kulturowe na Lotwie...

${ }^{90}$ WALKOWSKI, Bartłomiej. Pozostałości kultury materialnej starożytnych Greków na Półwyspie Iberyjskim. Propozycja szlaku muzealnego. In: Turystyka Kulturowa, 1, 2019, pp. 44-65.

${ }^{91}$ WYSOCKI, Tomasz. Powstała aplikacja dla miłośników historii: Odkryj Czeskie ślady we Wrocławiu. accessed November 4, 2020, https://visitwroclaw.eu/powstala-aplikacja-dla-milosnikow-historii-odkryj-czeskie-slady-we -wroclawiu.

${ }^{2}$ STEFAŃCZYK, Wiesław Tomasz. Mniejszość polska na Węrzech. Stan i potrzeby badań. In: Konteksty Kultury, 10(4), 2013, pp. 479-488.

${ }^{93}$ KOLODZIEJ, Daniela. Nauczanie historii Polski kandydatów pochodzenia polskiego ze Wschodu na studia w Polsce. In: Acta Universitatis Lodz̨iensis. Ksztatcenie Polonistyczne Cudzoz̧iemców, 7-8, 1996, pp. 177-183.

${ }^{94}$ GORDON, John E. Geotourism and cultural heritage. In: DOWLING, Ross, NEWSOME, David (eds.). Handbook of Geotourism. Cheltenham: Edward Elgar Publishing, 2018, pp. 61-75.

${ }^{95}$ BELTRAN-YANES, Esther, DONIZ-PAEZ, Javier, ESQUIVEL-SIGUT, Isabel. Chinyero Volcanic Landscape Trail (Canary Islands, Spain): A Geotourism Proposal to Identify Natural and Cultural Heritage in Volcanic Areas. In: Geosciences, 10(11), 2020, 453.

${ }^{96}$ DABEZIES, Heritagization of nature...
} 
capital and those that rendered great services to the city. Some of those commemorated are also known outside Austria and Poland.

Viennese Polonica are an excellent tool for disseminating the history and cultural heritage of Poland in Vienna. Polonica can also become objects of geotourism, combining both cultural and natural heritage. The popularisation of Viennese Polonica requires organised activities aimed at offering tourists a thematic route or an application for smartphones. The activities carried out so far by Polish institutions to promote Poland's heritage abroad are insufficient and do not use the potential of the Polonica located in the urban space of Vienna.

Objects commemorating people or events located in the city space are part of the cultural heritage of the country in which they are located and the homeland of the commemorated person. These objects are part of the common cultural heritage and may serve to strengthen ties between countries or deepen political disputes, depending on the interpretation of the message.

\section{Acknowledgments}

The research was financed by the Institute of Geography of the Pedagogical University of Krakow.

\section{References}

ASHWORTH, Gregory (2002). Holocaust tourism: The experience of Kraków-Kazimierz. In: International Research in Geographical and Environmental Education, 11(4), pp. 363-367. ISSN 1038-2046.

ASHWORTH, Gregory (2006). Editorial: On Icons and ICONS. In: International Journal of Heritage Studies, 12(5), pp. 392-393. ISSN 1470-3610.

ASHWORTH, Gregory, GRAHAM, Brian, TUNBRIDGE, John (2007). Pluralising Pasts: Heritage, Identity and Place in Multicultural Societies. London-Ann Arbor: Pluto Press. ISBN 978-17-83716-11-1.

Atlas polskiej obecności za granica (2014). Warszawa: Ministerstwo Spraw Zagranicznych, accessed October 11, 2020,

https://issuu.com/msz.gov.pl/docs/atlas_polskiej_obecnosci_za_granica. ISBN 978-8363743-64-2.

BANASZKIEWICZ, Magdalena, OWSIANOWSKA, Sabina (2015). Trudne dziedzictwo a turystyka. O dysonansie dziedzictwa kulturowego. In: Turystyka Kulturowa, 11, pp. 6-24. ISSN 1689-4642.

BELTRAN-YANES, Esther, DONIZ-PAEZ, Javier, ESQUIVEL-SIGUT, Isabel (2020). Chinyero Volcanic Landscape Trail (Canary Islands, Spain): A Geotourism Proposal to Identify Natural and Cultural Heritage in Volcanic Areas. In: Geosciences, 10(11), 453. ISSN 2076-3263.

BENDIX, Regina (2009). Heritage between Economy and Politics. An Assessment from the Perspective of Cultural Anthropology. In: SMITH, Laurajane, AKAWA, Natsuko (eds.).Intangible Heritage. London: Routledge, pp. 253-269. ISBN 978-04-15473-96-5.

BENEDIK, Christian, SCHRÖDER, Klaus Albrecht (2014). Die Gründung der Albertina - Herzog Albert und seine Zeit. Ostfildern: Hatje Cantz. ISBN 37-75-73824-X. 
BIAŁOKUR, Marek (2019). Defender of the Poniatowski family's honor. A story about Józef Antoni Poniatowski. In: Annales Collegii Nobilium Opolienses, 8, pp. 59-91. ISSN 2299-7687.

BYRNE, Denis (1996). Deep Nation: Australia's Acquisition of an Indigenous past. In: Aboriginal History, 20, pp. 82-107. ISSN 1837-9389.

CHYLIŃSKA, Dagmara, KOSMALA, Gerard (2011). Krajobraz po bitwie. Niewykorzystany potencjał turystyczny pól bitew na przykładzie wojen śląskich. In: WIDAWSKI, Krzysztof (ed.)- Turystyka kulturowa na Dolnym Ślasku - uybrane aspek.ty, Tom 2. Wrocław: Uniwersytet Wrocławski, pp. 33-70. ISBN 978-83-62673-15-5.

COLERIDGE, Henry James (1893). The story of St. Stanislaus Kostke of the Society of Jesus. London: Burns \& Oates.

CWANEK-FLOREK, Ewa (2006). Polnische Berühmtheiten im Spiegel der öffentlichen Erinnerung in Wien. Die Rezeption polnischer Spuren in derDonaumetropole. Marburg: Tectum Wissenschaftsverlag. ISBN 38-28-89198-5.

CWANEK-FLOREK, Ewa (2014). Wiedeńczyka o wiele więcej łączy z mieszkańcem Krakowa czy Budapesztu, aniżeli z mieszkańcem Berlina. Recepcja relacji polsko-austriackich z perspektywy „polskich” ulic w Wiedniu. In: KISZTELIŃSKA-WĘGRZYŃSKA, Agnieszka, KUCZYŃSKI, Krzysztof (eds.). Austria i relacje polsko-austriackie w XX $i$ XXI wieku. Polityka - kultura - gospodarka. Lódź: Wydawnictwo Uniwersytetu Lódzkiego, pp. 261279. ISBN 978-83-7969-455-6.

CZEPCZYŃSKI, Mariusz, SOOVALI-SEPPING, Helen (2016). From sacrum to profanum: reinterpretation of communist places of power in Baltic cities. In: Journal of Baltic Studies, 47(2), pp. 239-255. ISSN 0162-9778.

DABEZIES, Juan Martin (2018). Heritagization of nature and its influence on local ecological knowledge in Uruguay. In: International Journal of Heritage Studies, 24(8), 2018, pp. 828-842. ISSN 1470-3610.

DAVIES, Norman (1982). God's Playground, a History of Poland: The Origins to 1795. New York: Columbia University Press. ISBN 0-231-05350-9.

DAVIES, Norman (2005). God's Playground, a History of Poland, Vol. 2: 1795 to the Present. New York: Columbia University Press. ISBN 978-02-3112-819-3.

DŁUGOSZ, Dominika (2007). Śladami Włochów w Polsce od XVI do XVIII wieku. Region świętokrzyski. In: Rocznik Muzeum Narodowego w Kielcach, 23, pp. 167-192. ISSN 0137-2866.

DOWELL, Stuart. King Sobieski monument erected in Kraków after Vienna says it's too controversial. In: The First News, 19.11.2019. accessed December 17, 2020, https://www. thefirstnews.com/article/king-sobieski-monument-erected-in-krakow-after-vienna-says-itstoo-controversial-8780

FAIRCLOUGH, Graham (2009). New heritage frontiers. In: PALMER, Robert, ed. Heritage and Beyond. Strasbourg: Council of Europe Publishing, pp. 29-41. ISBN 978-92-871-6635-7.

FORST-BATTAGLIA, Jakub (1983). Polnisches Wien. Wien-München: Herold. ISBN 978-37008022-04.

GOCH, Marcin (2017). Zapomniane malarskie polonika w zbiorach muzeów Ukrainy. In: WALCZAK, Wojciech, LOPATECKI, Karol, eds. Stan badań nad wielokulturowym dziedzictwem dawnej Rzeczypospolitej, t. IX. Białystok: Instytut Badań nad Dziedzictwem Kulturowym Europy, pp. 383-394. ISBN 978-83-641031-86. 
GORDON, John E. (2018). Geotourism and cultural heritage. In: DOWLING, Ross, NEWSOME, David (eds.). Handbook of Geotourism. Cheltenham: Edward Elgar Publishing, pp. 61-75. ISBN 978-17-853688-51.

GÓRENOWICZ, Maria (2016). Akademickie prace Jana Ciaglińskiego (1858-1913). In: Art of Eastern Europe, 4, pp. 401-409. ISSN 2353-5709.

GRADZIŃSKI, Ryszard (1972). Przewodnik po okolicach Krakowa. Warszawa: Wydawnictwa geologiczne.

GRAHAM, Brian, ASHWORTH, Gregory, TUNBRIDGE, John (2000). A Geography of Heritage: Power, Culture, and Economy. London: Arnold. ISBN 978-03-406777-80.

GRANT, Hilary (2018). Heritage down the chute: the demolition of Saskatchewan's grain elevators. In: International Journal of Heritage Studies, 24(6), pp. 573-584. ISSN 1470-3610.

HALL, Stuart (1999). Whose Heritage? Un-settling “The Heritage", Re-imaging the PostNation. In: Third Text, 13(49), pp. 3-13. ISSN 1475-5297.

HARRISON, Rodney (2013). Heritage: critical approaches. New York: Routledge. ISBN 978-0203-10885-7.

HARVEY, David C. (2001). Heritage Pasts and Heritage Presents: Temporality, Meaning and the Scope of Heritage Studies. In: International Journal of Heritage Studies, 7(4), pp. 319-338. ISSN 1470-3610.

HEWISON, Robert (1987). The Heritage Industry: Britain in a Climate of Decline. London: Methuen. ISBN 04-13-16110-2.

HOMOLA-SKĄPSKA, Irena (1996). Krakowskie cukiernie i kawiarnie w XIX wieku. In: Annales Universitatis Mariae Curie-Skłodowska. Sectio F, Historia, 51, pp. 43-61. ISSN 02394251.

HOWARD, Peter (2003). Heritage. Management, Interpretation, Identity. London-New York: Continuum. ISBN 08-26-45898-X.

KIRSHENBLATT-GIMBLETT, Bárbara (2004). El patrimonio inmaterial como producción metacultural. In: Museum International, 221(222), pp. 52-65. ISSN 1468-0033.

KLUCZYCKI, Jakub F. (1835). Pamiqutki polskie w Wiedniu i jego okolicach. Jako też inne wiadomości tyczace sie Polakón, szrzególniej mieszłancón Galicji, Kraków: by the author.

KO\&ODZIEJ, Daniela (1996). Nauczanie historii Polski kandydatów pochodzenia polskiego ze Wschodu na studia w Polsce. In: Acta Universitatis Lodziensis. Ksærtatcenie Polonistyczne Cudzoziemców, 7-8, pp. 177-183. ISSN 0860-6587.

KOLODZIEJCZYK, Krzysztof Piotr (2015). Historyczne cmentarze i miejsca pamięci pogranicza nysko-jesenickiego jako walor krajoznawczy. In: Turystyka Kulturowa, 4, pp. 4173. ISSN 1689-4642.

KOMAROMI, Ann (2002). Wyspianski's Wesele: Poised on the Border. In: Theatre Journal, 54(2), pp. 187-202. ISSN 0192-2882.

KONSTANTYNÓW, Dariusz (ed.). (2016). Petersburg i Polska: zbiór esejów. Kraków: Międzynarodowe Centrum Kultury.

KOVACS, István, MITROVITS, Miklós (2019). Wegierskie pamiatki w Polsce. Budapest: Antall József Tudásközpont. ISBN 978-615-5559-52-5.

KRAJEWSKI, Kazimierz (2010). Ukraińskie miejsca pamięci narodowej na terenie Polski. In: Biuletyn Instytutu Pamięi Narodowej, 7-8, pp. 118-137. ISSN 1641-9561. 
KRUPA, Barbara, NAFPAKTITIS, Margarita (2017). Polonika w Bibliotece Uniwersytetu Stanforda w Kalifornii: unikalne kolekcje, trudności w gromadzeniu i udostępnianiu. In: Z Badań nad Ksiqżkeq i Ksiegozbiorami Historycznymi, Polonika w zbiorach obcych, spec. vol., pp. 557-566. ISSN 1897-0788.

KUC, Monika. Polonika w świecie na Google Arts \& Culture. In: Rzeczpospolita, 24.06.2020, accessed October 13, 2020, https://www.rp.pl/Spoleczenstwo/200629692-Polonika-wswiecie-na-Google-Arts--Culture.html.

KUNZ, Norbert (2017). Polonica der Bayerischen Staatsbibliothek - Bestände und digitale Dienstleistungen. In: Z Badań nad Ksiqżkq i Ksiegozbiorami Historycznymi, Polonika w zbiorach obcych, spec. vol., pp. 345-356. ISSN 1897-0788.

KUS, Eugeniusz, MAKOWSKA, Beata (2007). Wspólne dziedzictwo na Pomorzu. In: Ochrona Zabytków, 2, pp. 17-19. ISSN 0029-8247.

LOWENTHAL, David (1998). The Heritage Crusade and the Spoils of History. New York: Cambridge University Press. ISBN 05-21-63562-4.

LUSIŃSKA, Anna, KALINOWSKA-ŻELEŹNIK, Anna (2017). Promocja Polski i kultury polskiej za granicą w programie Ministerstwa Kultury i Dziedzictwa Narodowego. In: Media Biznes Kultura, 1(2), pp. 77-91. ISSN 2451-1986.

MACDONALD, Sharon (2009). Difficult Heritage. Negotiating the Nazi Past in Nuremberg and Beyond. London: Routledge. ISBN 04-15-41992-1.

MAGNIER, John (1908). Blessed Clement Mary Hofbauer. In: HERBERMANN, Charles (ed.). The Catholic Encyclopedia Vol. 4. New York: Robert Appleton Company, pp. 44-45.

MAŁKOWSKA-BIENIEK, Ewa (2009). Polskie judaika jako magnes turystyczny. In: Turystyka Kulturowa, 4, pp. 29-62. ISSN 1689-4642.

MATIĆ, Miloš (2011). Conceptualization of "Culture" within heritology as a paradigm. In: Anthropology, 11(1), pp. 117-142. ISSN 1452-7243.

NOWICKA-JEZOWA, Alina, TEODOROWICZ-HELLMAN, Ewa, eds. (2007). Polonica in the Swedish National Archives: The Skokloster Collection and Other Materials. Stockholm: Stockholms Universitet Slaviska Institutionen. ISBN: 91-87290-48-0.

OPYRCHA£, Leszek (2015). Rękopiśmienne plany Kamieńca Podolskiego w zbiorach Austriackiej Biblioteki Narodowej w Wiedniu. In: Przeglad Historyczno-Wojskowy, 16(67)/4(254), pp. 131-140. ISSN 1640-6281.

PARAFIANOWICZ, Halina (2018). Woodrow Wilson and Poland: Between Myth and Reality. Some Reflections. In: Białostockie Teki Historyczne, 16, pp. 129-145. ISSN 1425-1930.

PAWŁAK, Wojciech, CZEPIŃSKI, Łukasz, MAJCHRZYK, Aleksander, DUK, Katarzyna (2019). Przegląd skamieniałości kręgowców i flory z terenów dzisiejszej Polski zgromadzonych w Muzeum Historii Naturalnej w Wiedniu. In: Przeglad Geologiczny, 67(1), pp. 48-55. ISSN 0033-2151.

PENDLEBURY, John, WANG, Yi-Wen, LAW, Andrew (2018). Re-using "uncomfortable heritage": the case of the 1933 building, Shanghai. In: International Journal of Heritage Studies, 24(3), pp. 211-229. ISSN 1470-3610.

PESENDORFER, Franz, FISCHER, Gero (2002). Wiener Impressionen. Auf den Spuren polnischer Geschichte in Wien. Wien: Edition Volkshochschule. ISBN 39-00-79937-7.

PIASTA, Marek (2011). Polskie dziedzictwo kulturowe na Lotwie - niewykorzystany potencjał turystyczny. In: Turystyka Kulturowa, 8, pp. 30-49. ISSN 1689-4642. 
PIASTA, Marek, KAMEL, Marta (2013). Polskie dziedzictwo kulturowe w Estonii - potencjał turystyczny. In: Turystyka Kulturowa, 6, pp. 46-64. ISSN 1689-4642.

Portal Polonika. Warszawa: Ministerstwo Kultury i Dziedzictwa Narodowego, accessed October 11, 2020, http://www.polonika.gov.pl/pages/pl/idea-projektu.php

ROJEK, Katarzyna (2009). Znaczenie pamiątek i rekonstrukcji historycznych epoki napoleońskiej w Polsce dla rozwoju turystyki kulturowej (historyczno-biograficznej). In: Turystyka Kulturowa, 5, pp. 4-27. ISSN 1689-4642.

ROMAN, Wanda Krystyna (2019). Aby pamięć nie zginęła? Polskie Archiwum Wojenne (19151921) i jego zbiory. In: Archeion, 120, pp. 185-202. ISSN 0066-6041.

SAMSON, Jim (1980). The Music of Szymanowski, London: Kahn \& Averill. ISBN 0-90070758-5.

SCHWONEK, Matthew R. (2020). "Bidding up" the national cause: Józef Piłsudski and the Central Powers' Kingdom of Poland. In: First World War Studies, 11(1), pp. 1-20. ISSN 19475039.

SELIGER, Maren, UCAKAR, Karl (1985). Wien, Politische Geschichte 1740 -1934. WienMünchen: Jugend und Volk. ISBN 32-24-16050-0.

SKRODZKA, Agnieszka (2019). Polonika w kościele Notre-Dame de Bonsecours w Nancy. In: ROLSKA, Irena, ed. Studia nad sztuka renesansu i baroku. T. 14, Twórca i dzieło, Lublin: Towarzystwo Naukowe Katolickiego Uniwersytetu Lubelskiego Jana Pawła II, pp. 149-174. ISBN 978-83-7306-861-2.

SMITH, David J. (2008). "Woe from Stones" Commemoration, Identity Politics and Estonia's "War of Monuments". In: Journal of Baltic Studies, 39(4), pp. 419-430. ISSN 0162-9778.

SMITH, Laurajane (2006). Uses of Heritage. London: Routledge. ISBN 978-02-03602-26-3.

SMITH, Laurajane (2011). El "espejo patrimonial": illusion narcisista o reflexiones multiples? In: Antipoda: Revista de Antropología y Arqueología, pp. 39-63. ISSN 2011-4273.

STACHOWIAK, Andrzej (2015). Niemieckie cmentarze na Ziemiach Zachodnich jako miejsca niepamięci. In: Prace Etnograficzne, 43(2), pp. 123-140. ISSN 2299-9558.

STEFAŃCZYK, Wiesław Tomasz (2013). Mniejszość polska na Węrzech. Stan i potrzeby badań. In: Konteksty Kultury, 10(4), pp. 479-488. ISSN 2083-7658.

STONE, Elaine Murray (1997). Maximilian Kolbe, Saint of Auschwitz. New York: Paulist Press. ISBN 08-09-16637-2.

SZULC, Tad (1995). Pope John Paul II: The Biography. New York: Scribner. ISBN 978-0-68480416-3.

SZYMANOWSKI, Karol (1925). Zagadnienie,,ludowości”w stosunku do muzyki współczesnej. In: Musyka, 10, pp. 8-13.

ŠKOVIEROVA, Angela (2017). Polonica in the library of the Slavic Institute in Bratislava. In: Z Badań nad Ksiażka i Ksiegozbiorami Historycznymi, Polonika w zbiorach obych, spec. vol., pp. 381-386. ISSN 1897-0788.

TABORSKI, Roman (1974). W'sód wiedeńskich poloników. Kraków: Wydawnictwo Literackie. ISBN 83-08-00947-6.

TABORSKI, Roman (1992). Polacy w Wiedniu. Wrocław: Zakład Narodowy im. Ossolińskich. ISBN 83-04-03658-4.

TOMCZAK, Agnieszka (2016). Polish national branding in comparison to selected of Central and Eastern Europe. In: Journal of Modern Science, 29(2), pp. 153-174. ISSN 1734-2031. 
TUNBRIDGE, John (2013). Problems in selling heritage for tourism: A cautionary tale, with insight from European's (pen)insular margins. In: KAMINSKI, Jaime, BENSON, Angela, ARNOLD, David (eds.). Contemporary Issues in Cultural Heritage Tourism. London-New York: Routledge, pp. 59-70. ISBN 11-38-08201-5.

TUNBRIDGE, John, ASHWORTH, Gregory (1996). Dissonant Heritage. Chichester: Wiley. ISBN 978-04-71948-87-2.

TYGIELSKI, Wojciech (2010). Włosi. In: KOPCZYŃSKI, Michał, TYGIELSKI, Wojciech, eds. Pod wspólnym niebem. Narody dawnej Rzeczypospolitej. Warszawa: Muzeum Historii Polski, pp. 183-200. ISBN 978-83-11-11724-2.

UNTERREINER, Katrin, GREDLER, Willfried (2009). The Hofburg. Vienna: Pichler Verlag. ISBN 978-3-85431-491-2.

UZZELL, David (1989). Heritage Interpretation - Volume 1: The Natural and Built Environment. London: Belhaven. ISBN 978-1-852-93077-6.

UZZELL, David (1989). Heritage Interpretation - Volume 2: The Visitor Experience. London: Belhaven. ISBN 978-1-852-93078-3.

VECCO, Marilena (2010). A definition of cultural heritage: From the tangible to the intangible. In: Journal of Cultural Heritage, 11(3), pp. 321-324. ISSN 1296-2074.

WALKOWSKI, Bartłomiej (2019). Pozostałości kultury materialnej starożytnych Greków na Półwyspie Iberyjskim. Propozycja szlaku muzealnego. In: Turystyka Kulturowa, 1, pp. 44-65. ISSN 1689-4642.

WARCHOL-SCHLOTTMANN, Małgorzata (2007). Biblioteki polskie w Wiedniu. Od Ossolińskiego po dzień obecny. In: Prace Naukowe Uniwersytetu Ślaskiego w Katowicach, 2527, pp. 103-114. ISSN 0208-6336.

WATERTON, Emma (2010). Towards a Critical Heritage: Discourse, Policy and Power. Basingstoke: Palgrave Macmillan. ISBN 978-0-230-29238-3.

WENDERSKI, Michał (2015). "Dutch" settlements in Poland. How different were they actually? In: Werkwinkel, 10(1), pp. 51-64. ISSN 1896-3307.

Wielka Encyklopedia Powszechna PWN, tom 8, Warszawa, (1966), p. 837.

WYSOCKI, Tomasz (2020). Powstała aplikacja dla miłośników historii: Odkryj Czeskie ślady we Wrocławiu. accessed November 4th, https://visitwroclaw.eu/powstala-aplikacja-dlamilosnikow-historii-odkryj-czeskie-slady-we-wroclawiu.

ZAHEDPISHEH, Nahid, ABU BAKAR, Zulqarnain B., SAFFARI, Narges (2017). English for Tourism and Hospitality Purposes (ETP). In: English Language Teaching, 10, pp. 86-94. ISSN 1916-4742.

ZAMOYSKI, Adam (2010). Chopin: Prince of the Romantics. London: Harper Collins. ISBN 9780-00-735182-4.

ZIEMLEWSKA, Anna. Podstawa pomnika Jana III Sobieskiego na Kahlenbergu, accessed August 10, 2021, https://www.wilanow-palac.pl/sobiesciana/podstawa_pomnika_jana_iii_ sobieskiego_na_kahlenbergu_sobiesciana.html.

ZIĘBIŃSKA-WITEK, Anna (2020). Musealisation of communism, or how to create national identity in historical museums. In: Mureológia a kultúrne dedičstvo, 8(4), pp. 59-72. ISSN 13392204. 